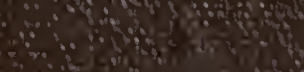

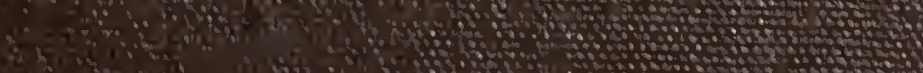

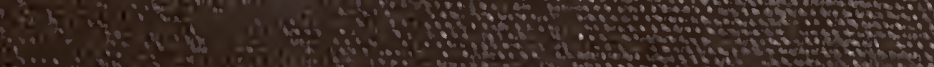
F

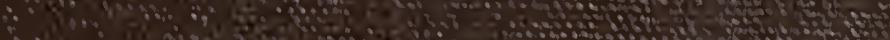
*

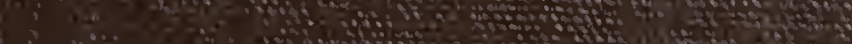

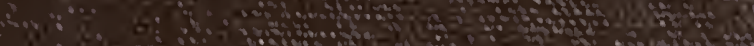

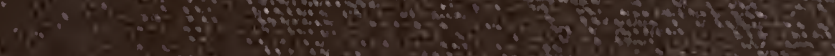

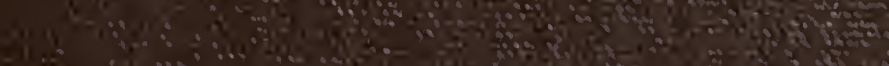

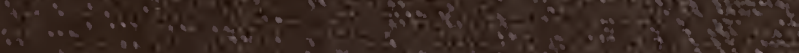

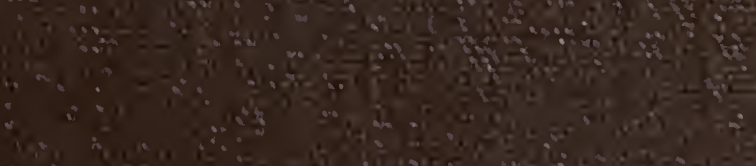

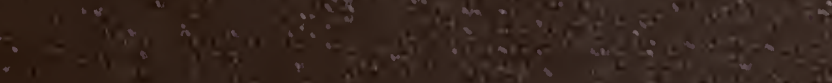

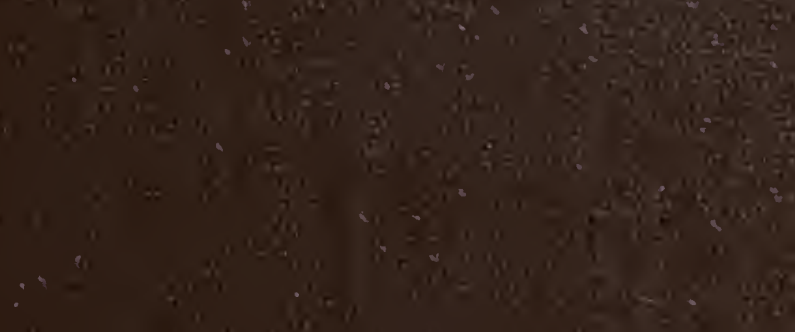

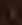

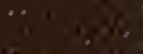

$\therefore$

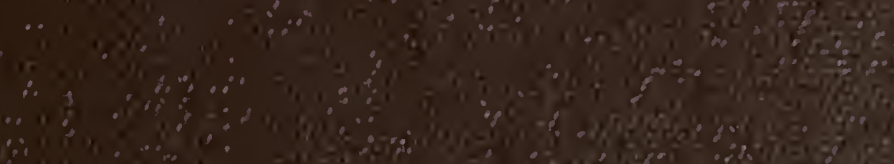

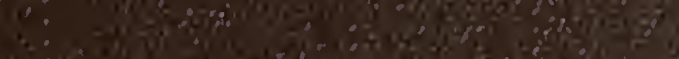

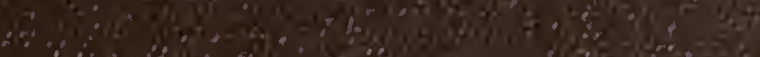

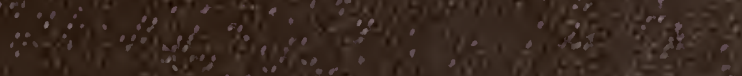

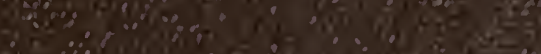

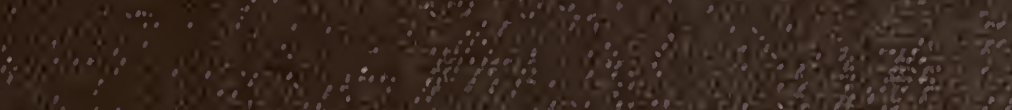




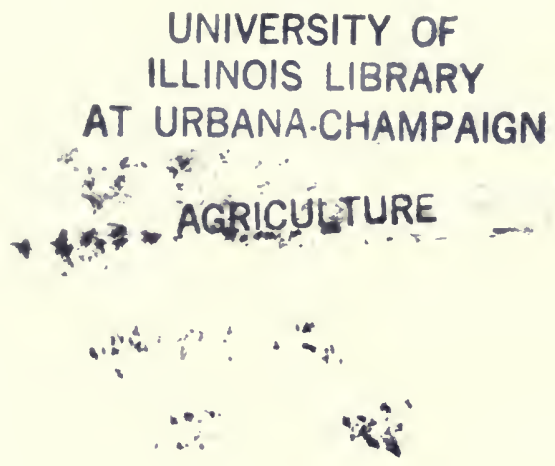




\section{Nitrogen Use}

\section{And Behavior}

\section{In Crop}

\section{Production}

\section{FRED WELCH}

\section{Bulletin 761}

Agricultural Experiment Station

College of Agriculture

University of Illinois at Urbana-Champaign 



\section{Nitrogen Use And Behavior In Crop Production \\ L. FRED WELCH}

\section{Bulletin 761}

Agricultural Experiment Station College of Agriculture University of Illinois at Urbana-Champaign 
Nitrogen and Its Uses. . . . . . . . . . . . . . . 4

Nitrogen in Corn and Soybean Production.............. 12

Uptake and Loss of Nitrogen. . . . . . . . . . . . . . . . 27

Chemical Methods of Conserving Fertilizer Nitrogen. . . . . . . . . 39

Leaching and Denitrification Studies................. 43

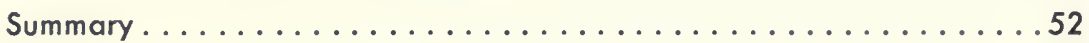

Literature Cited ............................ 54

This bulletin is one of six publications growing out of a four-and-a-halfyear study of nitrogen as an environmental quality factor. Although the study, including publication costs, was supported principally by a grant from the Rockefeller Foundation, the effort was initiated through a grant from the Illinois Agricultural Association. This phase of the study was supported through staff assistance provided by a number of state agencies, but in particular by the Illinois Agricultural Experiment Station and the Illinois State Water Survey.

Four other bulletins in the series have been published: "Nitrates, Nitrites, and Health," Bulletin 750; "Environmental Decision Making: The Role of Community Leaders," Bulletin 756; "Economic Effects of Controls on Nitrogen Fertilizer," Bulletin 757; and "Wells and Ponds: Water Quality and Supply," Bulletin 758. A book on nitrogen in relation to food, environment, and energy is being prepared as part of the series.

L. F. Welch is Professor of soil fertility in the Department of Agronomy, College of Agriculture, University of Illinois at Urbana-Champaign.

The author wishes to thank the following people: S. R. Aldrich, Assistant Director, Illinois Agricultural Experiment Station; R. J. Miller, formerly Associate Director, Illinois Agricultural Experiment Station, now Director, Idaho Agricultural Experiment Station; A. A. Bomke, former graduate assistant, now at the University of British Columbia, Vancouver, Canada; and C. IV. Boast, L. V. Boone, R. G. Hoeft, L. T. Kurtz, G. E. McKibben, D. L. Mulvaney, M. G. Oldham, T. R. Peck, F. J. Stevenson, M. D. Thorne, IV. M. Walker, and F. E. Zajicek, all of the Department of Agronomy, University of Illinois.

Urbona, Illinois

February, 1979

Publications in the bulletin series report the results of investigations made or sponsored by the Experiment Stotion. The Illinois Agricultural Experiment Station provides equal opportunities in progroms ond employment. $4 M-2-79-42381-S W$ 
$\mathrm{A}^{\prime \prime}$ 1 plants require large amounts of nitrogen for normal growth. Yet very few soils contain enough native nitrogen to sustain high yields in most crops; legumes are an exception. Agriculturalists have known for many years that the yields of nonlegumes usually increase when nitrogen from legumes and animal wastes is added to the natural levels stored in soil organic matter. Only within recent decades have large supplies of man-made inorganic nitrogen fertilizers become available at prices attractive to farmers in developed countries.

Modern agriculture now relies heavily on commercial nitrogen fertilizer. Without it, crop production would decline drastically and food prices would soar. Growers and managers have long been interested in management practices that promote maximum absorption of nitrogen fertilizer during plant growth. Improving uptake would of course reduce the amount of nitrogen lost into drainage water or as a gas into the atmosphere.

Until recently the incentive for efficient nitrogen management was economic. In the late 1960's and early 1970's, however, many people who had become concerned about the quality of the environment questioned the possible effects on human and livestock health when large amounts of nitrate-nitrogen leach into drinking water supplies (Deeb and Sloan, 1975). Also, some environmentalists postulated that high levels of nitrate in lakes and ponds would promote excessive growth of aquatic plants. Decomposing plants might then deplete the water of oxygen, leading eventually to stagnation, fish kills, and the eutrophication or "death" of impounded waters.

Having become energy-conscious during the mid-1970's, many segments of society are also now aware that the supply of natural gas, used in large quantities to make nitrogen fertilizer, is not limitless. One means of conserving this natural resource is to increase the efficiency of nitrogen fertilizer applied to crops. Concern for improving water quality, conserving fuel, and containing crop production costs led to the research reported here.

This report, part of a larger study of nitrogen in the environment, examines the agricultural need for nitrogen, its use, and its belavior when added to the soil. The effect of nitrogen on crop yields, the nitrate content of water draining from agricultural soils, and possible ways of reducing the amount of leached nitrogen are discussed. A better understanding of nitrogen behavior will, the author hopes, encourage efficient nitrogen management practices. 


\section{NITROGEN AND ITS USES}

Nitrogen, a colorless, odorless, tasteless gas, is present in the atmosphere in larger quantities than any other gas, occupying about 79 percent of the air by volume and 75 percent by weight. Above each acre of land the air contains about 35,000 short tons of nitrogen $(78,400$ metric tons/ha), none of which can be used directly by plants. Before becoming available to plants, atmospheric nitrogen must first be combined with oxygen or hydrogen.

Required in large amounts by all plants and animals, nitrogen is an essential part of the amino acids from which proteins are formed. Man and other animals obtain proteins, which are about 16 percent nitrogen, directly or indirectly from plants.

For our purposes here, crop plants are broadly divided into legumes and nonlegumes. Legumes, such as soybeans, clover, alfalfa, peanuts, and peas, in association with certain bacteria have the ability to use or "fix" nitrogen from the air. Under the proper conditions, the roots of legumes are invaded by beneficial bacteria of the genus Rhizobium, which multiply and stimulate the root to form nodules. The bacteria-legume association is symbiotic: through photosynthesis the plant produces food, some of which is translocated to the roots and used by the bacteria; in turn the bacteria in conjunction with the legume add hydrogen to atmospheric nitrogen to produce ammonium, a form of nitrogen that the plant can then use.

Most nonlegumes, on the other hand, lack the ability to convert atmospheric nitrogen into a useable form. The amount of nitrogen available to nonlegumes can be increased by adding nitrogen fertilizers and manure and by growing legumes before nonlegumes. The nitrogen combined with hydrogen and stored by legumes as proteins becomes available to other crop plants when decomposing legumes release nitrogen.

In the commercial manufacture of nitrogen fertilizers, atmospheric nitrogen $\left(\mathrm{N}_{2}\right)$, consisting of two nitrogen atoms with an exceptionally strong chemical bond, must first be broken up. The large amount of energy necessary for this process is supplied by fossil fuel. The nitrogen is then combined with hydrogen to form anhydrous ammonia $\left(\mathrm{NH}_{3}\right)$, in itself an effective fertilizer. Through further processing, the nitrogen combined with oxygen and other elements can be converted into other useful types of fertilizer, such as ammonium nitrate and urea.

During thunderstorms, lightning (electricity) causes atmospheric nitrogen and oxygen to combine. Rainfall brings these nitrogen oxides to the soil, where they become available for plant use. In terms of crop needs, the amount of nitrogen entering the soil this way is small, only 
5 to 13 pounds per acre ( 6 to $15 \mathrm{~kg} / \mathrm{ha}$ ). This amount may, however, significantly affect the nitrogen content of rivers and lakes. It should be pointed out that the nitrate ion is the same regardless of its source, and hence is a potential water pollutant whether it comes from precipitation, sewage, fertilizer, biological fixation, or industrial wastes.

\section{The Nitrogen Cycle}

Because nitrogen tends to return to the air, the supply is in no danger of being depleted by nitrogen-fixing legumes or by the manufacture of fertilizer. Coming from the atmosphere, nitrogen is cycled through plants, animals, and the soil, and eventually returns to the atmosphere (Figure 1). During this cycle, nitrogen undergoes a number of chemical changes through biological or industrial processes, but the atmospheric supply is always abundant.

Some of the nitrogen from precipitation, organic or inorganic fertilizers, and legumes is taken up by crops, which in turn are consumed by livestock and humans. When plants and animals die and decompose, proteins are broken down into ammonium $\left(\mathrm{NH}_{4}^{+}\right)$, a form that can be used again by plants. Through a process called nitrification, nitrifying bacteria in the soil convert ammonium to nitrite $\left(\mathrm{NO}_{2}{ }^{-}\right)$and then to nitrate $\left(\mathrm{NO}_{3}^{-}\right)$, a form that is also available to plants. This phase of the nitrogen cycle may repeat itself many times, or it may be interrupted by other organisms, called denitrifying bacteria, that change nitrogen back into its gaseous state. In this state nitrogen returns to the atmosphere to begin the cycle anew.

Some of the nitrate not absorbed by plants may, however, leach and thus find its way into shallow farm wells, ponds, lakes, streams, and groundwater. If heavily laden with nitrate, this water can contaminate drinking water supplies and stimulate the excessive growth of aquatic plants (Dickey and Lembke, 1978).

\section{Nitrogen in the Soil}

The plow layer of mineral soils may have as little as 500 pounds to more than 5,000 pounds of nitrogen per acre (560 to $5,600 \mathrm{~kg} / \mathrm{ha}$ ). About 95 percent of the nitrogen is contained in organic matter, but cannot be used by crops until it mineralizes, that is, converts from organic to inorganic forms. The first product of mineralization is ammonium $\left(\mathrm{NH}_{4}{ }^{+}\right)$. Although very water soluble, it does not readily leach from the root zone, because the positively-charged ion is held by the negatively-charged clay and humus. Some ammonium does leach in sandy soils. 


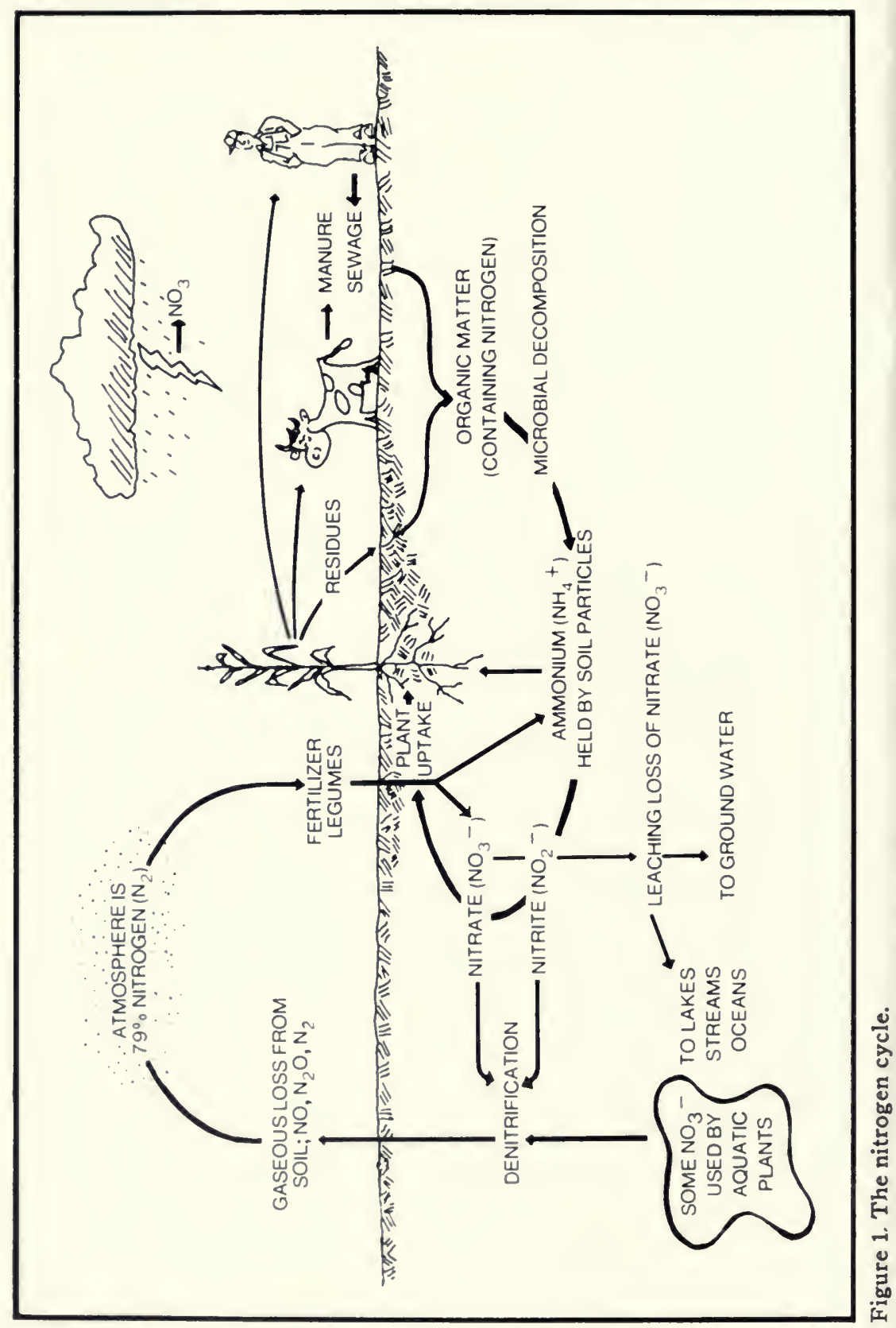


Only a temporary form of soil nitrogen, ammonium is converted by nitrifying bacteria to nitrite $\left(\mathrm{NO}_{2}{ }^{-}\right)$and then to nitrate $\left(\mathrm{NO}_{3}{ }^{-}\right)$, also a water-soluble form. Unlike ammonium, the negatively-charged nitrate is not held by clay, but leaches from the root zone when rainfall exceeds the rate of evapotranspiration. Nitrate may enter groundwater or appear in lakes and streams. Nitrate and ammonium may both be removed from soil by plant absorption. This process of converting nitrogen from an inorganic to an organic form is called immobilization.

Nitrate may also be lost by denitrification. In wet soils, which are low in oxygen, denitrifying bacteria use oxygen from the nitrate. Transformed to a gaseous state, nitrogen can then escape into the atmosphere, where it cannot of course be used by plants. Some studies indicate that 10 to 30 percent of the nitrogen fertilizer added to crops may be lost in this way (Broadbent and Clark, 1965). But denitrification can be helpful as well as harmful. For example, leached nitrate entering more anaerobic zones deeper in the soil may be denitrified before being carried into groundwater or lakes and streams. Still other ways nitrogen may be lost are by erosion and surface water runoff, although in these instances the nitrogen will usually be in organic rather than in soluble, inorganic forms. An exception occurs when surface-applied nitrogen is not incorporated on slopes, especially when the soil is frozen; in this case soluble, inorganic nitrogen losses due to runoff may be significant.

Fertilizers differ from some other materials commonly considered pollutants (Kurtz, 1970). For instance, garbage and sewage are sometimes applied to soil as a means of disposal, and certain man-made chemicals not ordinarily found in nature are applied to destroy weeds, insects, and diseases harmful to crops. Fertilizers, on the contrary, contain only chemical elements already present in soils. As Kurtz explains: "The problem of pollution from fertilizer, then, does not come from some new kind of exotic chemical that is just recently being added to the environment. The concern about pollution from fertilizer comes rather from problems that may result from an increase in the amount of plant nutrients in soils, waters, and streams. The problem is largely one of amount rather than the kind of substances being added."

\section{Organic Versus Commercial Nitrogen}

Farmers have traditionally relied on manure as a good source of plant nutrients. In 1905 a large supply of manure came from the 1.5 million horses and mules used as work animals on Illinois farms. Farmers needed to dispose of the manure, so they spread it on their fields. Until about 


\section{Table 1. - Effect of Manure on Corn Yields Averaged for Four Years at Twenty Locations in Illinois, 1939-1942}

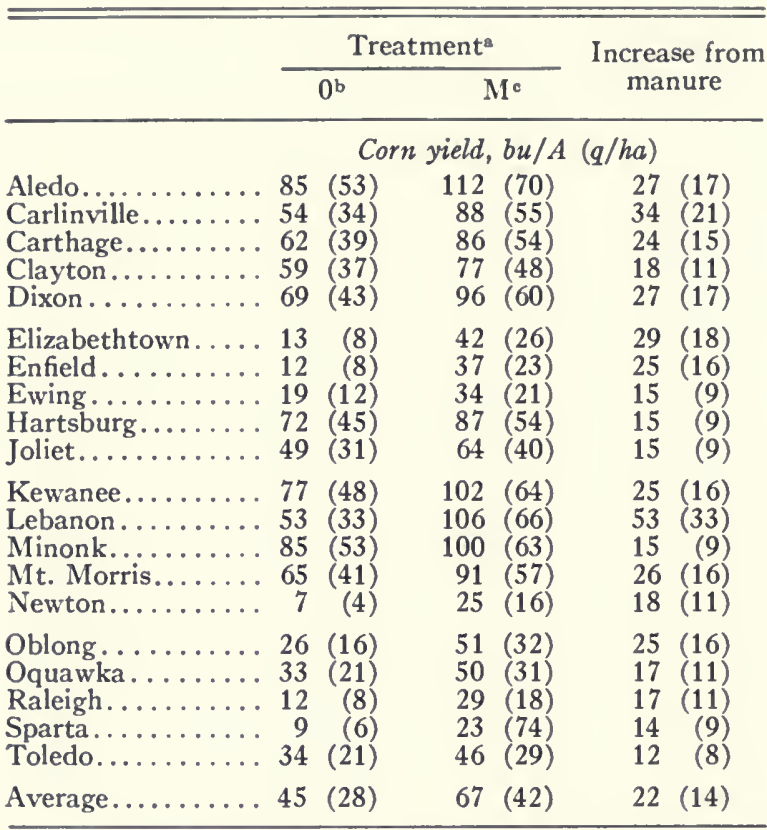

a Although yields are for 1939 to 1942, the treatments were generally started between 1910 and 1920 , depending on the location. The most common rotation was a four-year system that included legumes.

$b$ In treatment 0 all above-ground plant material was removed and not returned to the soil.

c In the manure treatment (M) the feed grain and all the hay and stover (cornstalks and small-grain straw) were removed and used for livestock feed and bedding, with the manure thus produced returned to the soil.

thirty years ago, when tractors all but replaced animal power, Illinois growers depended almost entirely on manure and legumes to supply nitrogen for nonleguminous plants. Although farmers who have large numbers of livestock still use the manure, today many Illinois farms have no livestock and hence no manure.

Studies by Bauer et al. (1945) indicate that corn yields at twenty locations in Illinois increased significantly when manure was added to the soil (Table 1). The smallest increase was 12 bushels per acre ( 8 $\mathrm{q} / \mathrm{ha}$ ) at Toledo, and the greatest increase was 53 bushels per acre ( 33 $\mathrm{q} / \mathrm{ha}$ ) at Lebanon. The average increase in yields for the twenty locations was 22 bushels per acre ( $14 \mathrm{q} / \mathrm{ha}$ ). Because manure contains several es- 


\section{Table 2. - Effect of Manure and Fertilizer on \\ Continuous Corn Yields Averaged for Four Years, Aledo, Illinois, 1963-1966}

\begin{tabular}{|c|c|c|}
\hline \multirow[b]{2}{*}{$\begin{array}{l}\text { Manure, ton/A } \\
(\text { metric ton/ha) }\end{array}$} & \multicolumn{2}{|c|}{ Fertilizer added, lb/A ( $\mathrm{kg} / \mathrm{ha})$} \\
\hline & None & $\begin{array}{l}\mathrm{N}_{1}, 160(180) \\
\mathrm{P}_{2} \mathrm{O}_{5}, 60(67) \\
\mathrm{K}_{2} \mathrm{O}, 60(67)\end{array}$ \\
\hline & \multicolumn{2}{|c|}{ Corn yield, bu/A ( $a / h a)$} \\
\hline 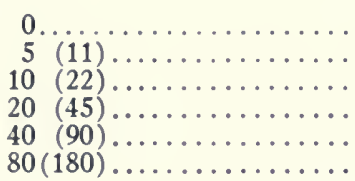 & $\begin{array}{r}62(39) \\
91(57) \\
. \quad 101(63) \\
105(66) \\
.105(74) \\
118(18)\end{array}$ & $\begin{array}{ll}124 & (78) \\
123 & (77) \\
121 & (76) \\
122 & (77) \\
130 & (81) \\
122 & (76)\end{array}$ \\
\hline
\end{tabular}

- These rates were applied five times from 1960 to 1966. The plots were limed in 1962 and the soil $\mathrm{pH}$ was about 6.2 .

sential plant nutrients, the yield increase cannot be attributed solely to nitrogen in the manure.

The value of natural organic materials versus commercial fertilizers has been vigorously debated during recent years. The data in Table 2 indicate that either source is equally effective in increasing corn yields. When 80 tons of manure was applied per acre (180 metric tons/ha), nothing was gained by adding 160 pounds of fertilizer nitrogen, 60 pounds of phosphorus $\left(\mathrm{P}_{2} \mathrm{O}_{3}\right)$, and 60 pounds of potassium $\left(\mathrm{K}_{2} \mathrm{O}\right)$ $(180,67$, and $67 \mathrm{~kg} / \mathrm{ha}$ ). Conversely, manure applied in addition to fertilizer had no further effect on yields. These results are not surprising: plants absorb few nutrients in the organic form, and the mineralized forms released from organic materials are the same as those in commercial fertilizers. In addition to supplying necessary plant nutrients, organic materials such as manure and the unharvested portion from field crops improve soil structure, thereby increasing the rate of water infiltration and decreasing soil erosion. Organic matter also makes tillage easier and creates a favorable environment for seedling emergence and plant growth.

Illinois farmers never had enough manure for the nutrient requirements of all crops, but now that farming is mechanized, even less manture is available. Also, yield expectations are three times higher than a few decades ago. Nevertheless, the large increase in corn yields from manuring suggest that growers who have manure should add it to the soil. The amounts of commercial nitrogen applied for Illinois corn should be reduced when manure is also applied. 


\section{Table 3. - Continuous Corn Yields With 100 Pounds of Nitrogen per Acre Being Supplied Annually by 800 Pounds of Dried Blood, Davenport Plots, Urbana, Illinois}

\begin{tabular}{|c|c|c|c|}
\hline & \multicolumn{2}{|c|}{ Soil treatment } & \multirow{2}{*}{$\begin{array}{l}\text { Increase } \\
\text { from } N\end{array}$} \\
\hline & $\mathrm{LNPK}^{\mathrm{a}}$ & LPK & \\
\hline & \multicolumn{3}{|c|}{ Corn yield, bu/A $(q / h a)$} \\
\hline $\begin{array}{l}1903 \ldots \ldots \ldots \ldots \ldots \\
1904 \ldots \ldots \ldots \ldots \ldots \ldots \\
1905 \ldots \ldots \ldots \ldots \ldots \\
1906 \ldots \ldots \ldots \ldots \ldots\end{array}$ & $\begin{array}{ll}55 & (34) \\
83 & (52) \\
58 & (36) \\
80 & (50) \\
69 & (43)\end{array}$ & $\begin{array}{ll}48 & (30) \\
66 & (41) \\
49 & (31) \\
58 & (36) \\
40 & (25)\end{array}$ & $\begin{array}{rr}7 & (4) \\
17 & (11) \\
9 & (6) \\
22 & (14) \\
29 & (18)\end{array}$ \\
\hline
\end{tabular}

a $\mathrm{L}=$ limestone, $\mathrm{N}=$ nitrogen, $\mathrm{P}=$ phosphorus, $\mathrm{K}=$ potas. sium. The cost of 100 pounds of nitrogen as dried blood was $\$ 20.40$; corn was worth 39 cents per bushel.

\section{Gradual Acceptance of Commercial Nitrogen}

Early Illinois settlers found millions of acres of soils rich in organic matter. As bacteria decomposed this material, nitrogen was converted from organic to inorganic forms, which became available for plant uptake. During the first decade of cultivation, the prairie soil was apparently too rich for wheat: the wheat tended to grow too tall and then fall over, or lodge, thus reducing grain yields. With continued cropping, the soil's storehouse of nitrogen slowly declined. When corn was grown continuously for fifty years without fertilizer on the Morrow Plots at Urbana, Illinois, organic nitrogen in the plow layer was reduced from 4,000 pounds per acre in 1904 to 2,300 pounds by 1953 (4,480 to 2,576 $\mathrm{kg} / \mathrm{ha}$ ), a reduction of 43 percent (Stevenson, 1965).

Research during the first quarter of this century indicated that the soil no longer had enough nitrogen for producing maximum yields when corn was grown year after year on experimental plots (Bauer et al., 1926). The data in Table 3 show that nitrogen supplied as dried blood increased yields by 7 to 29 bushels per acre ( 4 to $18 \mathrm{q} / \mathrm{ha}$ ), but this source of nitrogen was impractical because of the cost. Until about twenty-five years ago farmers commonly grew alfalfa, clovers, and other legumes to replenish soil organic nitrogen.

For many years the Department of Agronomy at the University of Illinois has operated research fields throughout the state to study the fertilizer needs of crops grown on different soils and in various cropping systems. Data from research conducted at ten of these fields between 1943 and 1948 are given in Table 4 (Miller and Lang, 1961). With 


\section{Table 4. - Effect of Fertilizer Nitrogen on Yields of First-Year Rotation Corn After Hay or Wheat at Ten Research Fields in Illinois, 1943-1948}

\begin{tabular}{|c|c|c|c|c|c|c|c|}
\hline & \multirow{2}{*}{$\begin{array}{l}\text { Cropping } \\
\text { system }^{2}\end{array}$} & \multicolumn{4}{|c|}{$\mathrm{N}, \mathrm{lb} / \mathrm{A}(\mathrm{kg} / \mathrm{ha})$} & \multirow{2}{*}{\multicolumn{2}{|c|}{$\begin{array}{l}\text { Increase } \\
\text { from N }\end{array}$}} \\
\hline & & & & & (90) & & \\
\hline & & \multicolumn{6}{|c|}{ Corn yield, bu/A $(q / h a)^{\mathrm{b}}$} \\
\hline $\begin{array}{l}\text { Aledo............. } \\
\text { Dixon .......... } \\
\text { Enfield......... } \\
\text { Hartsburg....... } \\
\text { Joliet........... }\end{array}$ & $\begin{array}{l}\text { CCOW } \\
\text { COHW } \\
\text { COWH } \\
\text { CCOW } \\
\text { CSCOWH }\end{array}$ & $\begin{array}{l}79 \\
92 \\
52 \\
80 \\
78\end{array}$ & $\begin{array}{l}(50) \\
(58) \\
(33) \\
(50) \\
(49)\end{array}$ & $\begin{array}{l}99 \\
98 \\
52 \\
83 \\
81\end{array}$ & $\begin{array}{l}(62) \\
(61) \\
(33) \\
(52) \\
(51)\end{array}$ & $\begin{array}{r}20 \\
6 \\
0 \\
3 \\
3\end{array}$ & $\begin{array}{r}(13) \\
(4) \\
(0) \\
(2) \\
(2)\end{array}$ \\
\hline $\begin{array}{l}\text { Kewanee.......... } \\
\text { McNabb......... } \\
\text { Minonk......... } \\
\text { Oblong......... } \\
\text { Raleigh........ }\end{array}$ & $\begin{array}{l}\text { CCOW } \\
\text { CCOW } \\
\text { CCOW } \\
\text { CSwH } \\
\text { COHW }\end{array}$ & $\begin{array}{l}63 \\
86 \\
79 \\
73 \\
56\end{array}$ & $\begin{array}{l}(40) \\
(54) \\
(50) \\
(46) \\
(35)\end{array}$ & $\begin{array}{l}86 \\
95 \\
81 \\
85 \\
61\end{array}$ & $\begin{array}{l}(54) \\
(60) \\
(51) \\
(53) \\
(38)\end{array}$ & $\begin{array}{r}23 \\
9 \\
2 \\
12 \\
5\end{array}$ & $\begin{array}{r}(14) \\
(6) \\
(1) \\
(8) \\
(3)\end{array}$ \\
\hline
\end{tabular}

n $\mathrm{C}=$ corn, $\mathrm{H}=$ hay, $\mathrm{O}=$ oats, $\mathrm{S}=$ soybeans, $\mathrm{W}=$ wheat. Legume was seeded in the small grains, crop residues were returned to the soil, and all plots received lime, phosphorus, and potassium.

Yields are four- to six-year averages from 1943 to 1948.

added nitrogen, corn-yield increases averaged about 8 bushels per acre ( $5 \mathrm{q} / \mathrm{ha}$ ), ranging from zero at Enfield to 23 bushels per acre ( $14 \mathrm{q} / \mathrm{ha}$ ) at Kewanee. At each of the locations, forage legumes were included in the cropping system, either as a year of standover hay or as a catch crop seeded in wheat. A catch crop is one that is seeded among another crop in early spring and left until late fall or the next spring. If left until the spring after that, the interseeded crop is referred to as standover. In either case, the legume was plowed under to provide some of the nitrogen needed by the following corn crop.

In the mid-1950's L. T. Kurtz (1959 report to farm advisers cooperating in nitrogen soil test study) coordinated research on farmers' fields throughout Illinois, using nitrogen rates of $0,50,100$, and 150 pounds per acre $(0,56,112$, and $168 \mathrm{~kg} / \mathrm{ha})$. In 1955 the average corn yields for the sixty-seven locations studied were 71 bushels per acre ( $45 \mathrm{q} / \mathrm{ha}$ ) without added nitrogen and 77 bushels ( $49 \mathrm{q} / \mathrm{ha}$ ) with added nitrogen, all three rates having been averaged. At nearly half of the research sites, yields increased by 6 or more bushels ( $4 \mathrm{q} / \mathrm{ha}$ ). In 1956 the average yields from the twenty-nine locations studied were 96 bushels without nitrogen and 107 bushels with nitrogen (60 and $67 \mathrm{q} / \mathrm{ha}$ ). Average increases might have been greater if plant populations had been higher. Eighteen of these sites had increases of 6 or more bushels, with the top five locations having an average increase of almost 31 bushels per acre (19 q/ha). 


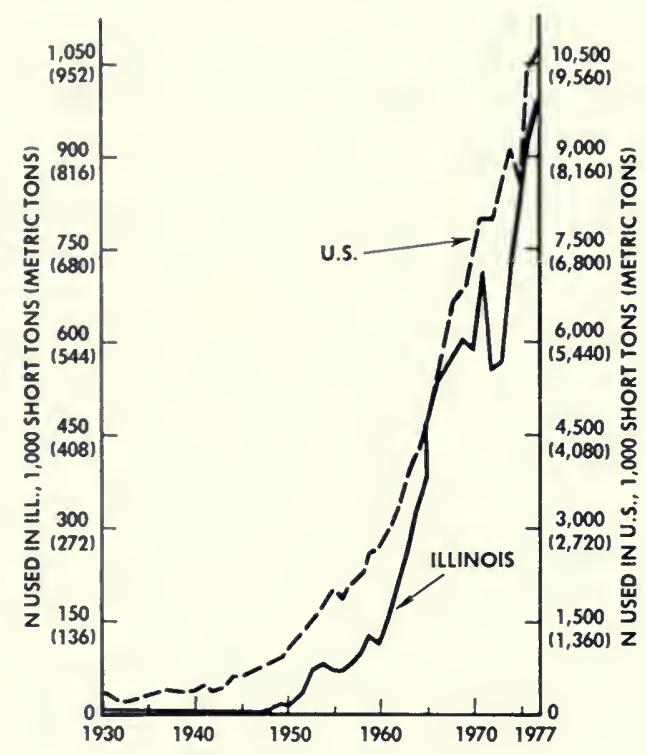

Figure 2. Fertilizer nitrogen used in the United States and in Illinois, 1930 through 1977. Illinois applies almost 10 percent of the national amount.

Yield-increase data from these and other earlier studies were encouraging; interest in commercial nitrogen fertilizers mounted. Since 1950, when Illinois growers added an average of only 3 pounds of nitrogen per acre $(3 \mathrm{~kg} / \mathrm{ha})$ to corn, application rates for some growers have leaped to more than 200 pounds per acre ( $224 \mathrm{~kg} / \mathrm{ha}$ ) in the 1970's.

\section{NITROGEN IN CORN AND SOYBEAN PRODUCTION}

Since the end of World War II there has been a spectacular increase in the use of commercial nitrogen fertilizer (Figure 2). In 1930 the United States used 378,000 tons of nitrogen, only 865 tons of which was used in Illinois (343,000 and 785 metric tons). In 1977 the amounts stood at 10.7 million tons for the United States and a little less than 1.0 million tons for Illinois (9.7 and 0.9 million metric tons). In 1966 and 1967 Illinois used more than 10 percent of the national amount; since that time Illinois usage has dropped to slightly less than 10 percent. Illinois usually uses more nitrogen fertilizer than any other state.

\section{Corn-to-Nitrogen Price Ratio}

About 90 percent of the nitrogen used in Illinois, a major cornproducing state, is applied to corn. Using large amounts of nitrogen 


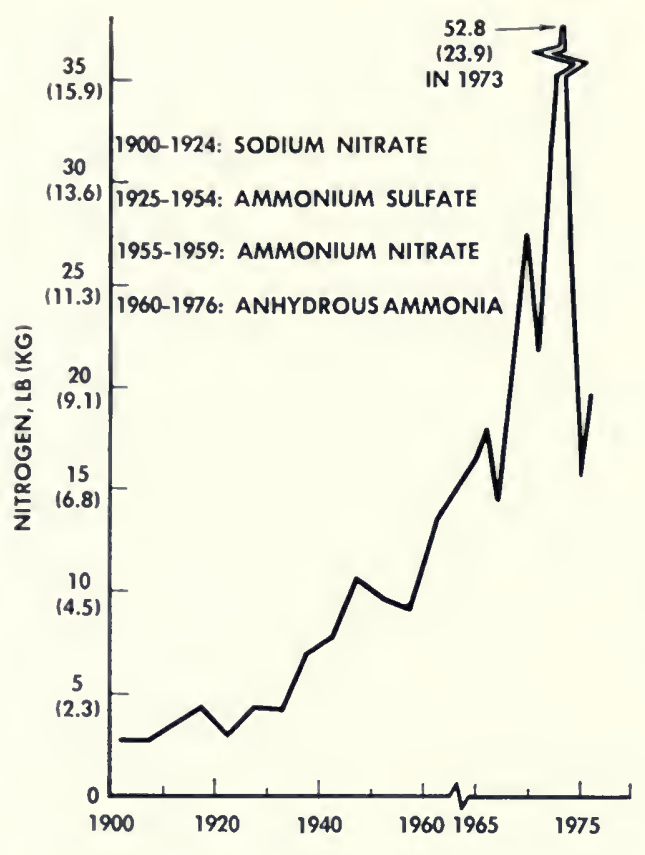

Figure 3. Nitrogen that 1 bushel $(25 \mathrm{~kg})$ of corn could buy during a given period. Data are averaged for fiveyear periods until 1965, then annually.

fertilizer has been economically feasible in recent years because of the favorable price of corn in relation to the price of nitrogen (Figure 3). From 1970 to 1975 one bushel of corn, weighing 56 pounds $(25 \mathrm{~kg})$, would purchase an average of 32.3 pounds of nitrogen $(14.7 \mathrm{~kg})$. This was not always the case: from 1900 to 1905 one bushel of corn would purchase only 2.9 pounds of fertilizer nitrogen $(1.3 \mathrm{~kg})$. The nitrogen purchasing power of corn improved over the years as corn prices went up and nitrogen prices went down. In 1917 one pound of nitrogen cost 34 cents, dropped to 5 cents from 1969 to 1973, but climbed back up to 11 cents in 1974 and 16 cents in 1975. Currently, one bushel of corn will buy about 17 pounds of fertilizer nitrogen $(7.7 \mathrm{~kg})$.

\section{Relationship Between Nitrogen and Crops}

\section{NITROGEN CONTENT OF CORN GRAIN}

As corn grows and matures throughout the spring and summer, nitrogen taken from the soil is stored in various parts of the plant. At the time of harvest, the grain contains about 70 percent of the nitrogen in the above-ground parts. Because of its direct relation to protein content, the nitrogen content of corn has interested scientists for a long 


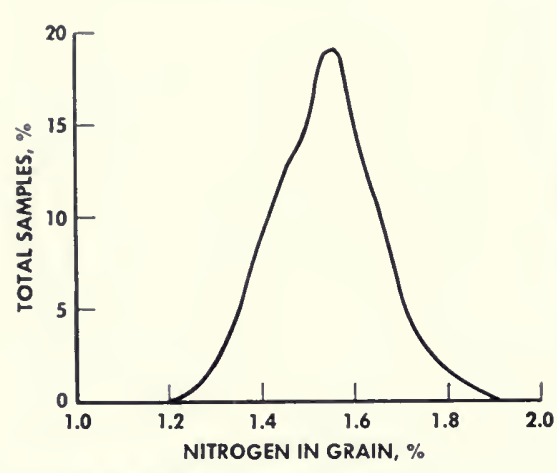

Figure 4. Frequency distribution for percentage of nitrogen in corn grain. Distribution was determined from 573 grain samples collected from five sites.

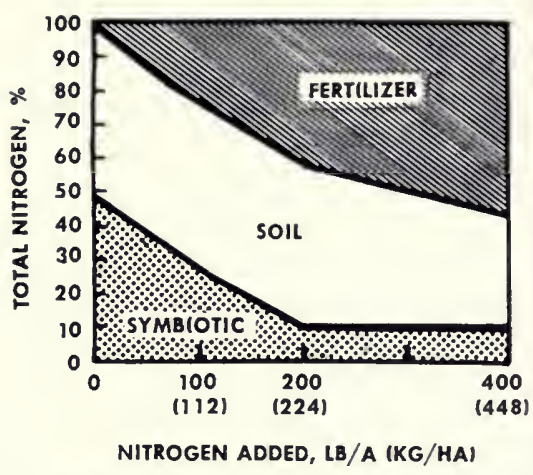

Figure 5. Precent total nitrogen in soybeans derived from symbiotic, soil, and fertilizer sources, as affected by rate of fertilizer nitrogen.

time. In this study, knowing how much nitrogen is contained in corn grain is especially important in trying to account for the nitrogen fertilizer removed from the soil in relation to the amount added.

To determine the percentage of total nitrogen in corn, 573 grain samples were collected from experimental plots at five locations where commercial corn variety trials were being conducted (Boone and Welch, 1972). All of the plots were fertilized with enough nitrogen to produce high yields. Calculations for nitrogen content were based on 15.5 percent moisture in the grain.

The frequency distribution for the percentage of nitrogen in corn grain is given in Figure 4. The highest percent nitrogen in any of the samples was 1.73; the lowest, 1.08 . Of the 573 samples, 80.5 percent contained between 1.22 and 1.49 percent nitrogen. The average was 1.38 percent, or 0.77 pounds of nitrogen per bushel of corn $(0.35 \mathrm{~kg} / 25 \mathrm{~kg})$. This value is lower than values reported in some textbooks (e.g., Tisdale and Nelson, 1975), but agrees closely with Barber and Olson (1968). The 1.38 percent nitrogen is equivalent to 8.6 percent protein.

\section{NITROGEN REMOVED BY SOYBEANS}

Soybean production is second only to corn in Illinois. To assess how this important crop influences the nitrogen status of Illinois soils, Johnson et al. (1975) conducted a study to determine how much nitrogen soybeans obtain from fertilizer, from soil, and from symbiotic fixation. For this purpose we used two soybean strains of the same variety, a normally nodulating strain and a specially bred non-nodulating strain. The non-nodulating soybeans could obtain nitrogen only from fertilizer 
and soil, whereas the nodulating strain could also symbiotically fix nitrogen from the atmosphere. Each strain was grown with and without added fertilizer nitrogen. To trace and measure the amount of fertilizer nitrogen absorbed by the two strains, we used labeled fertilizer, ${ }^{15} \mathrm{~N}$, which is "heavier" than the ${ }^{14} \mathrm{~N}$ commonly found in fertilizer and soil.

When no fertilizer nitrogen was added, fixation provided 48 percent of the nitrogen used by soybeans; the soil provided 52 percent (Figure 5 ). As the fertilizer rate was increased, the amount of nitrogen from fixation decreased. When 200 pounds of fertilizer per acre was added (224 kg/ha), only 10 percent of the total nitrogen came from fixation. The added fertilizer merely caused a shift in the amounts of nitrogen used from different sources. As shown in Table 5, nitrogen fertilizer did not appreciably increase the total nitrogen in soybeans (grain plus aboveground stover) or significantly affect yield.

The data indicate that nitrogen is symbiotically fixed only if needed by the soybeans. Nitrogen-fixing bacteria are active when soil nitrogen is low and relatively inactive when it is high. Thus the bacteria-soybean complex does not add excessive amounts of unused nitrogen to the environment. Furthermore, fertilizer nitrogen added for nonlegumes but not removed by them will be absorbed by soybeans.

As indicated in the Johnson study (1975), each 60-pound bushel of soybean grain contains 4 pounds of nitrogen, 1.48 pounds of which is the net amount removed from the soil $(27,1.81$, and $0.67 \mathrm{~kg}$, respectively). The following steps, which include only the above-ground portion of the plant, show how this net amount is calculated:

Nitrogen in plant

In grain.................. $76 \%$ of the total, or $4 \mathrm{lb} / \mathrm{bu}$

In stover ................. $24 \%$ of the total, or $1.26 \mathrm{lb} / \mathrm{bu}$ Source of nitrogen in plant

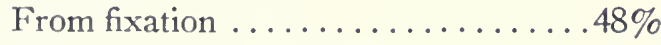

From soil ....................

Net removal of nitrogen from the soil is equal to removal of soil nitrogen by the grain minus symbiotically fixed nitrogen added to the soil by stover. Thus:

Nitrogen removed from soil by grain. . .52\% $\times 4 \mathrm{lb} / \mathrm{bu}=2.08 \mathrm{lb} / \mathrm{bu}$ Fixed nitrogen added to soil by stover. . . 48\% $\times 1.26 \mathrm{lb} / \mathrm{bu}=0.60 \mathrm{lb} / \mathrm{bu}$

$$
\text { Net nitrogen removed from soil }=1.48 \mathrm{lb} / \mathrm{bu}
$$

This net removal value is only a guideline for Illinois soils. For a soil low in plant-available nitrogen, symbiotic fixation would be high, so that the net removal of soil nitrogen would be lower than the 1.48 pounds per 


\section{Table 5. - Effect of Fertilizer Nitrogen on Soybean Yields and Nitrogen Content of Grain Plus Above-Ground Stover, Urbana, Illinois}

\begin{tabular}{|c|c|c|}
\hline $\begin{array}{l}\text { Fertilizer N, } \\
\mathrm{lb} / \mathrm{A}(\mathrm{kg} / \mathrm{ha})\end{array}$ & $\begin{array}{c}\mathrm{N} \text { in grain plus stover, } \\
\mathrm{lb} / \mathrm{A}(\mathrm{kg} / \mathrm{ha})\end{array}$ & $\begin{array}{c}\text { Yield, } \\
\text { bu/A (q/ha) }\end{array}$ \\
\hline $\begin{array}{l}0 \ldots(112) \\
100 \\
200(224) . \\
400(448) .\end{array}$ & $\begin{array}{lll}\ldots \ldots & 192 & (215) \\
\ldots \ldots & 203 & (227) \\
\ldots \ldots & 188 & (211) \\
\ldots \ldots & 203 & (227)\end{array}$ & $\begin{array}{ll}42 & (28) \\
42 & (28) \\
41 & (28) \\
44 & (30)\end{array}$ \\
\hline
\end{tabular}

bushel. If the soil is extremely deficient in nitrogen, then there may even be net addition rather than removal when soybeans are grown. Conversely, if the soil nitrogen is higher than in our study (with no nitrogen fertilizer added), then the net removed would probably be higher than 1.48 pounds per bushel $(0.67 \mathrm{~kg} / 27 \mathrm{~kg})$.

If some of the nitrogen fertilizer applied to previous crops stays in the soil, soybeans will absorb this residual fertilizer, and symbiotic fixation will be reduced. Because plant uptake would prevent leaching that might otherwise occur, this reduction might be considered beneficial from an environmental standpoint if soybean yields were increased by fertilizer nitrogen. Since yields are not affected, however, it would be more efficient to have nonlegumes rather than soybeans absorb the residual nitrogen. Additional evidence that added nitrogen does not increase soybean yields is given on page 37 .

\section{NITROGEN BALANCE SHEET}

During the past two and a half decades the use of commercial fertilizer for Illinois crop production has skyrocketed. Much but by no means all of this nitrogen is removed when crops, particularly corn, are harvested. Until commercial fertilizer was used regularly, the amount of nitrogen removed exceeded the amount added. Currently the reverse is true for corn: more nitrogen is added to the soil than is removed by the crop. Figure 6 presents a nitrogen balance sheet for corn, wheat, and soybeans. Per bushel, the nitrogen in corn weighs 0.77 pounds; in soybeans, 1.48 pounds (net removed from soil); and in wheat, 1.25 pounds $(0.35,0.67$, and $0.57 \mathrm{~kg}$, respectively). To calculate the nitrogen removed, the per-bushel weight of nitrogen in harvested grain was multiplied by per-acre yields averaged for the state. In an earlier report, Welch (1972) presents the total nitrogen added and removed collectively by agronomic crops in Illinois.

In 1950 thirteen times more nitrogen was removed in corn grain than was added as commercial fertilizer -39.3 versus 3.0 pounds per acre 


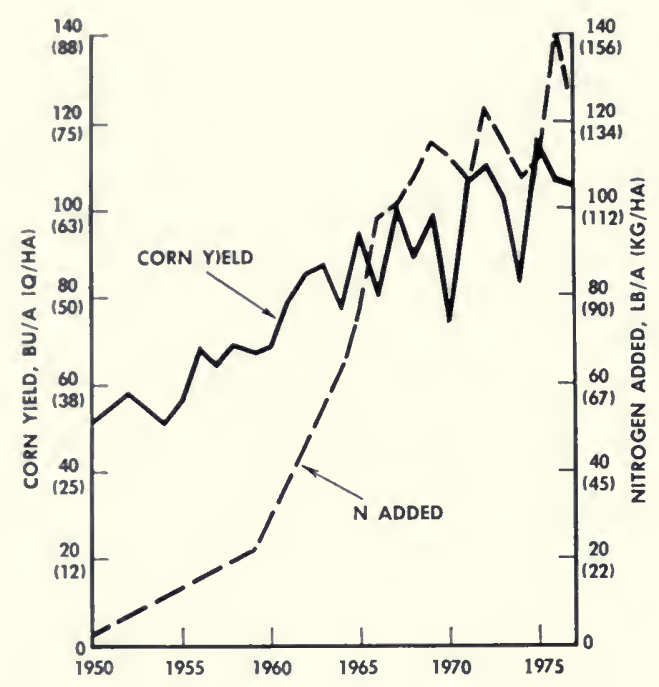

Figure 7. Illinois state-average corn yields and fertilizer nitrogen added.

added can only be determined by research. Nevertheless, from an environmental viewpoint these data do suggest that more fertilizer nitrogen is likely to have left the field in water in 1970 than in 1950.

The balance for wheat is considerably more favorable environmentally than it is for corn. In recent years there has not been much difference between the amount of nitrogen added and the amount removed in the grain (Figure 6A). In 1971, 1973, 1974, and 1976 more nitrogen was removed than was added.

For soybeans, the net nitrogen removed has usually exceeded that added by about 45 pounds per acre $(50 \mathrm{~kg} / \mathrm{ha})$ during the past decade (Figure 6B). As discussed in the previous section, adding nitrogen fertilizer has virtually no effect on soybean yields, and growers add little or no nitrogen. Some of this net nitrogen removed in recent years has undoubtedly come from the nitrogen added for corn but not absorbed by it; soybeans are often planted after corn in Illinois.

\section{NITROGEN USE AND CORN YIELDS}

Corn and soybeans occupy far larger acreages than any other agronomic crops in Illinois. Because soybeans receive almost no commercial nitrogen and corn receives a great deal, acreage shifts from soybeans to corn and vice versa can cause rapid changes in the total nitrogen used in the state.

Although the increase in both per-acre corn yields and per-acre nitrogen application since 1950 has been striking, corn yields have generally not increased as rapidly as nitrogen application (Figure 7). Yields have 
about doubled, but per-acre nitrogen use has jumped by as much as fortyfold. In 1973 average per-acre corn yields were 103 bushels with 116 pounds of nitrogen applied ( $65 \mathrm{q} / \mathrm{ha}$ and $130 \mathrm{~kg} / \mathrm{ha}$ ), up from the 1950 averages of 51 bushels of corn and 3 pounds of nitrogen $(32 \mathrm{q} / \mathrm{ha}$ and $3.4 \mathrm{~kg} / \mathrm{ha}$ ). Between 1950 and 1973 corn became increasingly dependent on fertilizer nitrogen as acreages of legumes other than soybeans declined and the percentage of farms with livestock, which supplied manure, dropped off.

\section{Carriers of Nitrogen Fertilizer}

Regardless of the form in which nitrogen is first applied, nitrate is the end product of any nitrogen fertilizer that remains in the soil for a period of time. When not taken up by the crop, nitrogen in the nitrate form is a potential contaminant if it leaches into water. But nitrate may be lost by denitrification as well as by leaching, so a low recovery of fertilizer nitrogen by plants does not necessarily mean that high leaching with subsequent adverse effects on water quality has occurred. Either leaching or denitrification may explain the loss if yields are low when a less efficient form of nitrogen has been properly applied. We are interested in minimizing losses so that a specified yield can be produced with less nitrogen, thus improving economic return and reducing unwanted effects on the environment.

Commercial nitrogen fertilizer is available in several forms: nitrate $\left(\mathrm{NO}_{3}{ }^{-}\right)$, ammonium $\left(\mathrm{NH}_{4}{ }^{+}\right)$, or compounds such as urea $\left(\mathrm{CO}\left(\mathrm{NH}_{2}\right)_{2}\right)$ and anhydrous ammonia $\left(\mathrm{NH}_{3}\right)$; these latter two compounds form ammonium soon after application. Unlike nitrate, which is an "unprotected" form of nitrogen, ammonium is considered "protected" because it is not lost by leaching or denitrification. If, however, the ammonium-producing fertilizers are not properly managed, some nitrogen may be lost to the atmosphere. Ammonium $\left(\mathrm{NH}_{4}\right)$ and ammonia $\left(\mathrm{NH}_{3}\right)$ occur together in aqueous solution, the proportion of each depending on the $\mathrm{pH}$, with the ammonia portion increasing as $\mathrm{pH}$ increases. The ammonia form, a gas, may be lost to the atmosphere when urea is applied but not incorporated into the soil by tillage or rainfall. Ammonia may also escape from the anhydrous form if the soil slit from the applicator knife is not sealed or if the ammonia is not placed deep enough in the soil.

Compared with ammonium nitrate, urea has advantages but also potential disadvantages. Fifty percent of the nitrogen in ammonimm nitrate $\left(\mathrm{NH}_{4} \mathrm{NO}_{3}\right)$ is present as nitrate $\left(\mathrm{NO}_{3}{ }^{-}\right)$, part of which may be lost shortly after application when conditions favor leaching and denitrification. Urea $\left(\mathrm{CO}\left(\mathrm{NH}_{2}\right)_{2}\right)$, on the other hand, hydrolyzes to form ammonium carbonate but then must be nitrified before nitrogen can be 

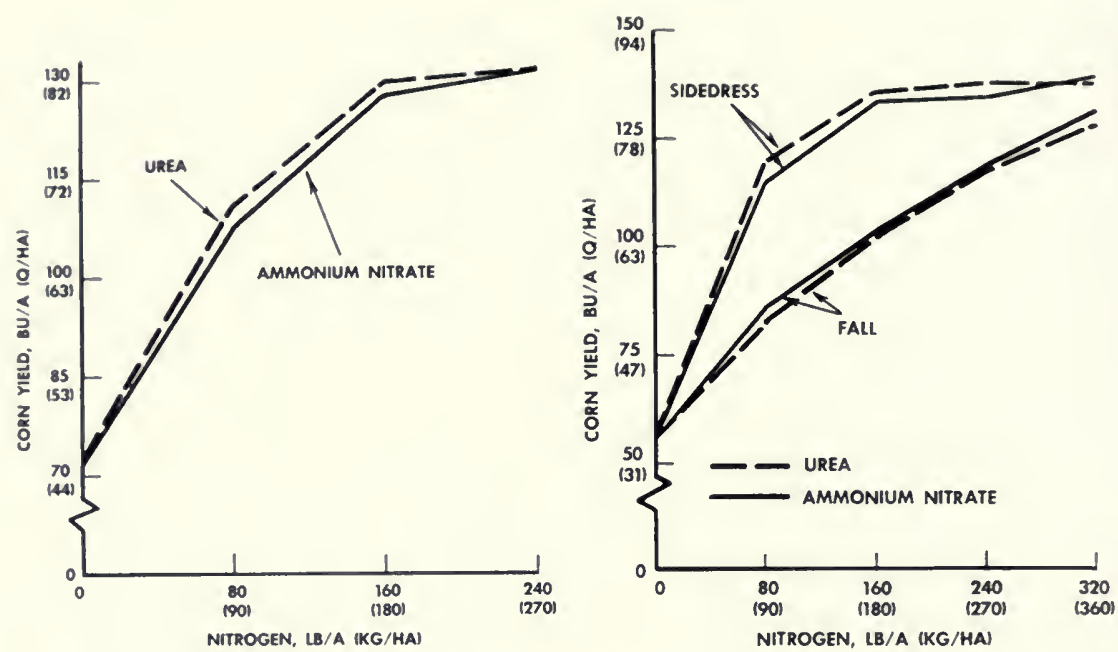

Figure 8. Effect of spring-applied urea Figure 9. Corn yields with urea and and ammonium nitrate on corn yields, ammonium nitrate fall-applied and Dixon, Ill., 1969 to $1973,1975$.

sidedressed, DeKalb, Ill., 1969 to 1972.

lost. Urea would seem to have the advantage because of this delay before it might be lost. The potential disadvantage of urea is that the ammonium carbonate formed from urea after hydrolysis increases the soil $\mathrm{pH}$ around the urea granule, the elevated $\mathrm{pH}$ favoring the loss of nitrogen as ammonia gas. Volatilization can be easily prevented, however, by incorporating urea into the soil soon after application. The effectiveness of early incorporation was borne out in studies at DeKalb and Dixon, Illinois, by Mulvaney et al. (1976), who determined that urea ancl ammonium nitrate were equally effective in increasing corn yields (Figures 8 and 9).

In the DeKalb study, application was by fall incorporation, spring preplant incorporation, and sidedressing, which is done after plants emerge. The results of spring preplant incorporation, not shown in Figure 9, were similar to those for sidedressing. With fall application the ammonium formed by urea might have been expected to persist longer than that from ammonium nitrate, but such was not the case, judging by the equal yields obtained with the two nitrogen fertilizers. Apparently urea liydrolyzed and nitrified rapidly enough so that there was no difference in the amount of nitrogen lost from the two fertilizers. Corn yields were significantly lower with fall application than with sidedressing, an indication that considerable amounts of nitrogen from both fertilizers were lost during winter or early spring. Mulvaney et al. had no way of 
determining in their study if the loss was from leaching or from denitrification.

Unlike the methods used at Dixon and DeKalb, the methods in a third study at Dixon Springs included leaving plant residues on the soil surface and not mechanically incorporating the fertilizer (McKibben, 1975). At Dixon Springs corn was planted in tall fescue with no tillage except for that in the rows made by the planter. Considerable plant material was present during spring preplant and sidedress applications of nitrogen, with the result that some urea granules lodged on this material. Under these conditions, nitrogen in the urea form is more likely to volatilize than the nitrogen from ammonium nitrate. Volatilization is presumed to be the reason that urea was noticeably less effective than ammonium nitrate in increasing corn yields. Otherwise, the amounts of nitrogen lost through leaching and denitrification are likely to be similar for these two fertilizers.

\section{Cropping Systems and Nitrogen Needs}

With the upsurge of commercial nitrogen manufacture and use, cropping systems have undergone significant changes in recent decades. Illinois growers used to rely heavily on symbiotically fixed nitrogen to help supply the nitrogen needs of nonlegumes. Cropping systems were often three- to six-year rotations that included one or more years of alfalfa, clover, or other forage legume. A crop such as corn with a high nitrogen requirement followed the legume, which was used as forage for the livestock raised on most farms. Farms thus had two sources of nitrogen manure and forage legumes - whereas today many growers have neither.

Factors other than nitrogen must also be considered when evaluating yield increases. Crop rotation, for example, may do much more than change the nitrogen status of the soil. By altering the field environment, rotations may discourage certain diseases and weeds that tend to persist from one year to the next when continuous corn is grown, although it should be kept in mind that rotations sometimes aggravate other pest problems. Rotations may improve the physical condition of the soil, thereby promoting infiltration and availability of water for crop use. Soil erosion can be controlled somewhat by rotation, although the degree of control depends on the amount of plant cover from a particular crop and the changes it encourages in the physical properties of the soil.

\section{CONTINUOUS CORN VERSUS CORN-SOYBEANS}

To illustrate the influence of the cropping system on yields, Mulvanes et al. (1976) studied several rotations at Elwood, Illinois. from 1972 


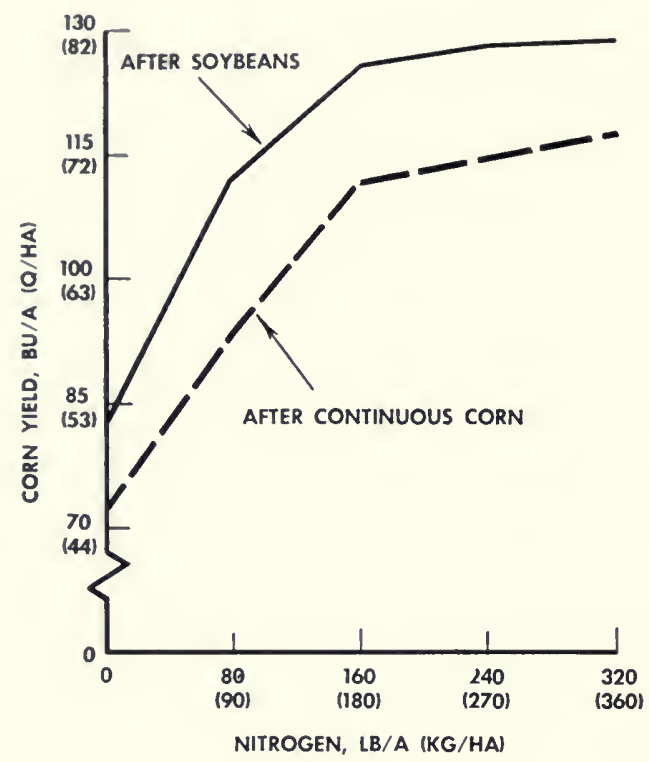

Figure 10. Corn yields as affected by two cropping systems (continuous corn and corn-soybeans) and fertilizer nitrogen, Elwood, Illinois, 1972 to 1975.

through 1975. They found that yields from corn following soybeans were higher than yields from corn following corn (Figure 10). Although yield differences were perhaps understandable when little or no nitrogen fertilizer was applied, these differences might reasonably have been expected to disappear at high fertilizer rates. Even at high rates, however, corn yielded about 12 bushels more per acre ( $8 \mathrm{q} / \mathrm{ha})$ after soybeans than after corn. Clearly, the amount of available nitrogen was not the only factor affecting yield.

M. G. Oldham (personal communication) drew a similar conclusion from the results of research at Urbana's Morrow Plots (Table 6). All plots in the Oldham study received 320 pounds of nitrogen per acre ( 360 $\mathrm{kg} / \mathrm{ha}$ ), an amount that should have been more than adequate for the corn yields obtained. Yet average yields for the study period were 24 bushels per acre higher $(15 \mathrm{q} / \mathrm{ha})$ for corn following soybeans than for continuous corn.

\section{CONTINUOUS CORN VERSUS CORN-CORN-OATS}

Another study compared the effects of added nitrogen on yields from continuous corn and from first- and second-year corn in a three-year rotation of corn-corn-oats, with clover seeded in the oats (Figure 11). The greatest yield differences between the two cropping systems occurred when no fertilizer nitrogen was added. With no added nitrogen, yields 


\section{Table 6. - Yields of Continuous Corn and Corn Following Soybeans, Morrow Plots, Urbana, Illinois ${ }^{\mathrm{a}}$}

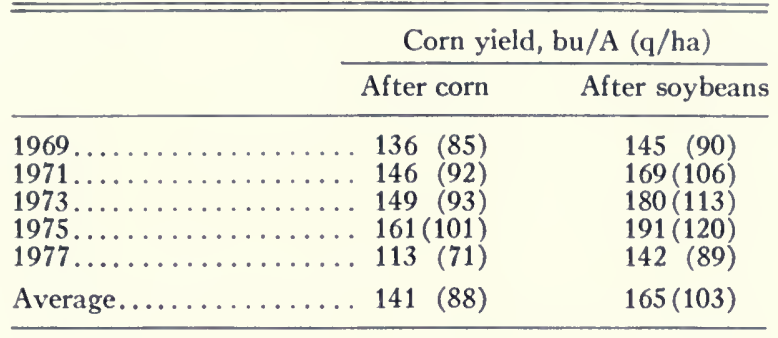

- The corn crops were fertilized at the rate of 320 pounds of nitrogen per acre $(360 \mathrm{~kg} / \mathrm{ha})$.

from first- and second-year rotation corn were 52 and 23 bushels per acre higher ( 33 and $14 \mathrm{q} / \mathrm{ha}$ ) than yields from continuous corn. With 80 pounds of nitrogen added per acre (90 kg/ha), continuous corn yielded 110 bushels per acre ( $69 \mathrm{q} / \mathrm{ha})$, a mere 1 bushel more than first-year corn with no added nitrogen. This finding indicates that the extra nitrogen supplied by clover to first-year corn, with no other nitrogen added, was equivalent to about 80 pounds of fertilizer nitrogen. With 160 pounds of nitrogen $(180 \mathrm{~kg} / \mathrm{ha})$, yields from first- and second-year corn were 7 and 4 bushels per acre higher ( 4.4 and $2.5 \mathrm{q} / \mathrm{ha}$ ) than yields from continuous corn. Even at 240 pounds of nitrogen per acre $(270 \mathrm{~kg} / \mathrm{ha})$ continuous corn still yielded less than rotation corn.

As in the corn-soybean rotation studies, these data suggest that some plant growth factor other than simple differences in the amounts of available nitrogen accounts for the yield variations between cropping systems. Clover seeded in oats obviously provided some nitrogen for the corn that followed, but not enough to meet the entire nitrogen requirement of first-year let alone second-year corn. Yields increased 33 bushels per acre $(21 \mathrm{q} / \mathrm{ha})$ when 240 pounds of fertilizer nitrogen was added per acre. However, the combination of added nitrogen plus a rotation that included a forage legume led to corn yields higher than those from rotation alone or from continuous corn with added nitrogen. The data available from this study provided no evidence about nitrate lost from continuous corn receiving nitrogen fertilizer versus that lost from rotation corn receiving nitrogen from legumes. Deep soil samples from the plots would surely have been helpful.

Rotation corn must undoubtedly absorb the same quantity of nitrogen that continuous corn absorbs if yields are equal. Consequently, the different sources of nitrogen, that is, initially organic versus inorganic, 


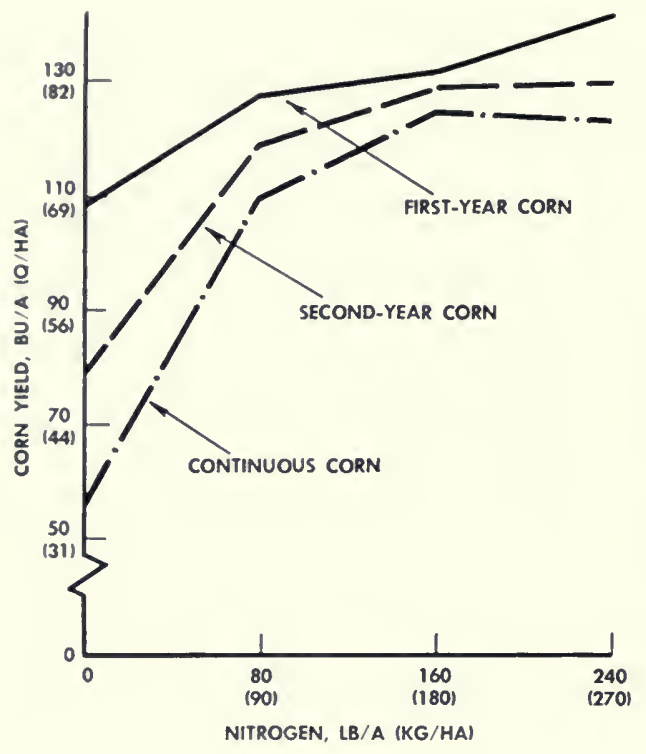

Figure 11. Effect of added nitrogen on yields of continuous corn versus first-year and second-year corn in a three-year rotation of corncorn-oats, with clover seeded in the oats, Kewanee, Illinois, 1970 to 1974.

must be evaluated in a rotation experiment. If the organic sources are mineralized only shortly before plant uptake, then these sources probably contributed less nitrate to leaching water than did the inorganic sources. On the other hand, if organic nitrogen mineralized when a crop was not growing, organic rather than inorganic nitrogen would contribute more nitrate to surface and underground waters.

For economic as well as for environmental reasons, researchers need to find out what factors besides nitrogen promote high yields in rotation corn. Having done so, agronomists might by some means other than rotation be able to duplicate and even augment the favorable effects of rotation.

\section{Diminishing Returns}

When crop yields are plotted against added fertilizer, a diminishingreturns curve usually emerges. With reference to crops, "diminishing returns" means that the yield increase from each additional increment of fertilizer is less than from the previous increment. At high rates yields no longer increase, and may actually decrease at very high rates.

During the eight-year period from 1968 through 1975, corn grown at the Hartsburg Agronomy Field in central Illinois was fertilized at five rates of nitrogen. The rates rose by increments of 60 pounds per acre to a maximum of 240 pounds (67 and $268 \mathrm{~kg} / \mathrm{ha}$ ). The yields, 
averaged for the eight-year period at each of the five rates, were as follows:

\begin{tabular}{rr}
\multicolumn{2}{c}{ Nitrogen } \\
$\mathrm{lb} / \mathrm{A}$ & $\mathrm{kg} / \mathrm{ha}$ \\
\hline 0 & 0 \\
60 & 67 \\
120 & 134 \\
180 & 201 \\
240 & 268
\end{tabular}

\begin{tabular}{cc}
\multicolumn{2}{c}{ Corn yield } \\
bu/A & q/ha \\
\hline 78 & 48.9 \\
119 & 74.6 \\
142 & 89.0 \\
152 & 95.3 \\
153 & 95.9
\end{tabular}

For discussion purposes, actual yields were used to calculate a mathematical equation that predicted the yields at 30-pound $(34 \mathrm{~kg})$ increments, as shown in Table 7.

The diminishing returns from nitrogen added to corn can be seen by comparing the data for yield increase and the amount of nitrogen recovered in the grain (Table 7 and Figure 12). The first 30-pound increment of nitrogen required 1.43 pounds of added nitrogen per acre $(2.58 \mathrm{~kg} / \mathrm{ha}$ per q) to increase the yield 1 bushel, while the increment from 180 to 210 pounds of nitrogen per acre required 30 pounds for a

Table 7. - Diminishing Refurns of Corn Yield Increases and Recovery of Fertilizer Nitrogen in Grain, Hartsburg, Illinois, 1968-1975

\begin{tabular}{|c|c|c|c|c|c|c|}
\hline \multirow{3}{*}{$\underset{(\mathrm{kg} / \mathrm{ha})}{\mathrm{N} / \mathrm{A}}$} & \multirow{3}{*}{$\begin{array}{l}\text { Corn, } \\
\text { bu/A } \\
\text { (q/ha) }\end{array}$} & \multicolumn{4}{|c|}{ For each $30-\mathrm{lb}(34-\mathrm{kg})$ increment of $\mathrm{N}$} & \multirow{3}{*}{$\begin{array}{c}\text { Estimated } \\
\text { cumulative } \\
\text { change in soil } \\
\mathrm{N}, \mathrm{lb} / \mathrm{A} \\
(\mathrm{kg} / \mathrm{ha})\end{array}$} \\
\hline & & \multirow{2}{*}{$\begin{array}{c}\text { Additional } \\
\text { corn, bu/A } \\
\text { (q/ha) }\end{array}$} & \multirow{2}{*}{$\begin{array}{l}\mathrm{N}, \mathrm{lb} / \mathrm{A} \text { to } \\
\text { produce } 1 \\
\text { bu corn } \\
\text { ( } \mathrm{kg} / \mathrm{ha} \\
\text { per q corn) }\end{array}$} & \multicolumn{2}{|c|}{$\begin{array}{c}N \text { recovered } \\
\text { by grain }\end{array}$} & \\
\hline & & & & $\begin{array}{c}\mathrm{Lb} / \mathrm{A} \\
(\mathrm{kg} / \mathrm{ha})\end{array}$ & $\begin{array}{l}\text { As } \% \text { of } \\
\text { added N }\end{array}$ & \\
\hline $0 \ldots \ldots$ & $\begin{array}{l}79 \\
(49.5)\end{array}$ & - & . & . & $\cdots$ & $\begin{array}{l}-63 \\
(-71)\end{array}$ \\
\hline $\begin{array}{c}30 \ldots \ldots \\
(34) \ldots \ldots\end{array}$ & $\begin{array}{l}100 \\
(62.7)\end{array}$ & $\begin{array}{l}21 \\
(13.2)\end{array}$ & $\begin{array}{c}1.43 \\
(2.58)\end{array}$ & $\begin{array}{c}16.8 \\
(18.8)\end{array}$ & 56 & $\begin{array}{l}-50 \\
(-56)\end{array}$ \\
\hline $\begin{array}{c}60 \ldots \ldots \\
(67) \ldots \ldots\end{array}$ & $\begin{array}{l}117 \\
(73.4)\end{array}$ & $(17)$ & $\begin{array}{c}1.76 \\
(3.18)\end{array}$ & $\begin{array}{l}13.6 \\
(15.2)\end{array}$ & 45 & $\begin{array}{l}-34 \\
(-38)\end{array}$ \\
\hline $\begin{array}{r}90 \ldots \ldots \\
(101) \ldots \ldots\end{array}$ & $\begin{array}{l}131 \\
(82.1)\end{array}$ & $\begin{array}{l}14 \\
(8.8)\end{array}$ & $\begin{array}{c}2.14 \\
(3.86)\end{array}$ & $\begin{array}{l}11.2 \\
(12.5)\end{array}$ & 37 & $\begin{array}{l}-15 \\
(-17)\end{array}$ \\
\hline $\begin{array}{r}120 \ldots \ldots \\
(134) \ldots \ldots\end{array}$ & $\begin{array}{l}142 \\
(89.0)\end{array}$ & $\begin{array}{l}11 \\
(6.9)\end{array}$ & $\begin{array}{c}2.73 \\
(4.92)\end{array}$ & $\begin{array}{l}8.8 \\
(9.9)\end{array}$ & 29 & $\begin{array}{c}6 \\
(7)\end{array}$ \\
\hline $\begin{array}{c}150 \ldots \ldots \\
(168) \ldots \ldots\end{array}$ & $\begin{array}{l}150 \\
(94.0)\end{array}$ & $\begin{array}{l}8 \\
(5.0)\end{array}$ & $\begin{array}{c}3.75 \\
(6.80)\end{array}$ & $\begin{array}{c}6.4 \\
(7.2)\end{array}$ & 21 & $\begin{array}{c}30 \\
(34)\end{array}$ \\
\hline $\begin{array}{c}180 \ldots \ldots \\
(201) \ldots \ldots\end{array}$ & $\begin{array}{l}154 \\
(96.6)\end{array}$ & $\stackrel{4}{(2.5)}$ & $\begin{array}{c}7.50 \\
(13.60)\end{array}$ & $\begin{array}{c}3.2 \\
(3.6)\end{array}$ & 11 & $\begin{array}{c}57 \\
(6-4)\end{array}$ \\
\hline $\begin{array}{r}210 \ldots \ldots \\
(235) \ldots \ldots\end{array}$ & $\begin{array}{l}155 \\
(97.2)\end{array}$ & $\stackrel{1}{(0.6)}$ & $\begin{array}{c}30.00 \\
(56.67)\end{array}$ & $\begin{array}{c}0.8 \\
(0.9)\end{array}$ & 3 & $\begin{array}{c}86 \\
(96)\end{array}$ \\
\hline $\begin{array}{r}240 \ldots \ldots \\
(268) \ldots \ldots \\
\end{array}$ & $\begin{array}{l}155 \\
(97.2)\end{array}$ & $\begin{array}{c}0 \\
(0)\end{array}$ & . & $\begin{array}{c}0 \\
(0)\end{array}$ & 0 & $\begin{array}{c}116 \\
(130)\end{array}$ \\
\hline
\end{tabular}



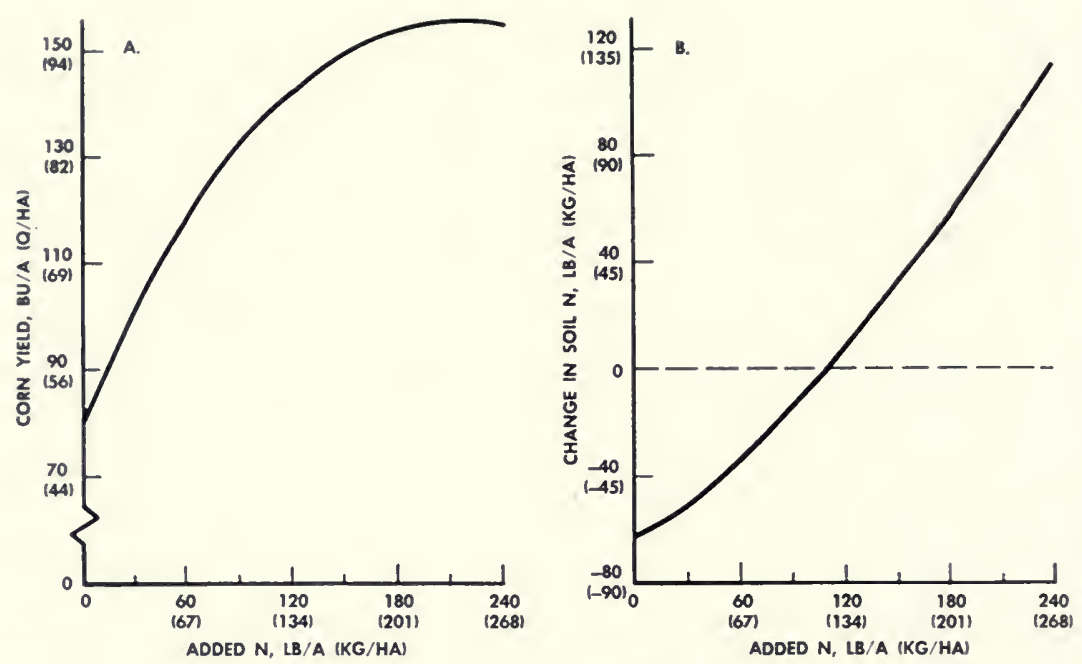

Figure 12. Corn yields and estimated change in soil nitrogen with added nitrogen, Hartsburg, Illinois, 1968 to 1975.

yield increase of 1 bushel ( $56.67 \mathrm{~kg} /$ ha per q corn). This diminishing yield increase means that the crop recovers little of the added nitrogen at high rates. With the first 30 -pound increment 56 percent of the added nitrogen was removed from the field in harvested grain, but with the increment from 180 to 210 pounds only 3 percent was removed. The percentage of added nitrogen recovered in the grain is of particular concern because inorganic nitrogen remaining in the soil may leach. Nitrogen in organic forms such as unharvested stover will of course not leach immediately, but may do so after it mineralizes and nitrifies.

Data in Table 7 and Figure 12 reflect the estimated cumulative changes in soil nitrogen for each increment of added nitrogen. These changes range from -63 to 116 pounds per acre for nitrogen rates of zero to 240 pounds per acre ( -71 to $130 \mathrm{~kg} / \mathrm{ha}$ and 0 to $268 \mathrm{~kg} / \mathrm{ha}$, respectively). A minus value means that the soil contains less nitrogen after harvest than before planting. The amount of soil nitrogen was not changed by cropping with 110 pounds of nitrogen $(123 \mathrm{~kg} / \mathrm{ha})$. These calculated values ignore nitrogen lost through leaching, denitrification, volatilization, or erosion. The data suggest some of the risks in using too little or too much fertilizer nitrogen. With no nitrogen added, current yields are low, but future yields will be even lower as soil nitrogen is depleted year after year. On the other hand, with 240 pounds of nitrogen applied per acre, yields are high, but 116 pounds of nitrogen per 
acre remains in the soil. Some of this nitrogen may leach and increase the nitrate content of water draining from the soil.

On the basis of the Hartsburg data, economics alone dictate that it would be unwise to add more than 180 pounds of nitrogen per acre. This is the most profitable rate, but 57 pounds ( $64 \mathrm{~kg} / \mathrm{ha}$ ) is not removed in grain. Although some of the nitrogen that remains would be in stover, it would eventually be returned to the soil. With no added nitrogen, the cost of producing 1 bushel of corn was $\$ 2.78$; with 180 pounds added per acre the cost was $\$ 1.70$. These cost values allowed no profit for the grower. Failure to apply nitrogen to continuous corn would drastically raise the per-unit production cost of corn, an increase that would ultimately be passed on to consumers. The economics of nitrogen fertilizer is discussed in greater detail in Swanson et al. (1973 and 1978).

The Hartsburg data indicate that the potential for nitrogen loss is greatest when the high nitrogen increments produce little or no yield increase. Excessive rates should be discouraged so as to protect the environment, conserve energy, and contain production costs. Good management is the key to minimizing water pollution from nitrogen fertilizer.

\section{UPTAKE AND LOSS OF NITROGEN}

\section{Practices Affecting Uptake by Corn}

As yields increase, the amount of nitrogen absorbed by plants increases. Any practice that improves yields will therefore improve the efficiency of a crop's use of a given rate of added nitrogen. Greater plant uptake of nitrogen means of course that less leachable nitrogen will remain in the soil after the crop matures. Many factors influence nitrogen utilization, among them, planting date, plant nutrients other than nitrogen, uniformity of nitrogen application, soil $\mathrm{pH}$, availability of water, the variety planted, light, planting rate, temperature, and biological conditions such as weeds, insects, and diseases. The sections that follow examine the first three of these factors.

\section{PLANTING DATE}

Planting corn early usually increases yields. Research supporting this conclusion was carried out at Elwood, Illinois, where corn was planted during the early, mid, and late parts of the planting season from 1972 through 1975 (Figure 13). With nitrogen applied at the rate of 240 pounds per acre, yields from the earliest plantings were an average of 17 bushels per acre ligher $(11 \mathrm{q} / \mathrm{ha})$ than yields from the second planting:: yields from the second plantings were 6 bushels higher ( $4 \mathrm{~kg} / \mathrm{ha}$ ) than 


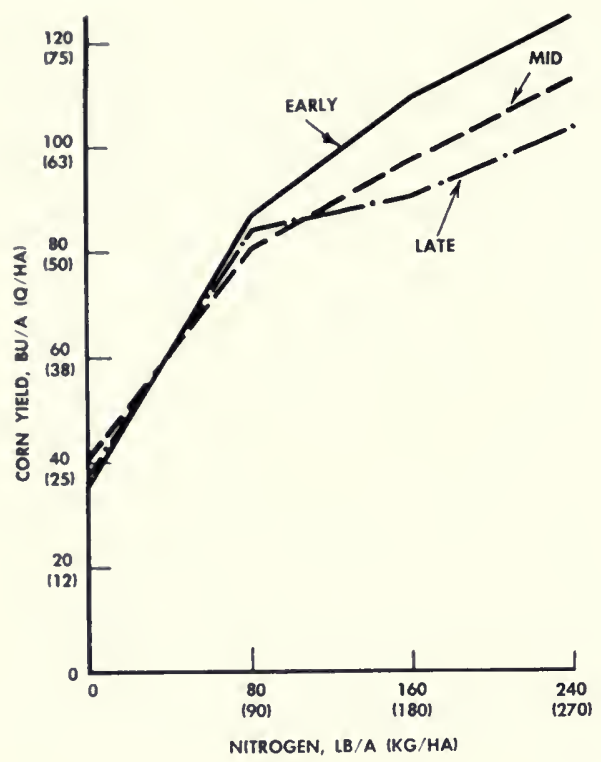

Figure 13. Effect of nitrogen on yields of corn planted during the early, mid, and late parts of the planting season, Elwood, Illinois. The earliest plantings were on May 4, 17, 2, 6 for 1972, 1973, 1974, and 1975, respectively; mid, May $12,24,29,17$; and late, May 22, June 2, 5, May 28. Population was 24,000 plants per acre $(59,000 /$ ha $)$.

from the third. On the basis of these differences, the 23 additional bushels ( $15 \mathrm{q} / \mathrm{ha})$ of corn from the earliest planting dates should have left 18 fewer pounds of potentially leachable nitrogen $(20 \mathrm{~kg} / \mathrm{ha})$ in each acre of soil than corn from the latest dates.

Even at the 80 - and 160 -pound (90 and $180 \mathrm{~kg} / \mathrm{ha}$ ) nitrogen rates, early planting resulted in greater nitrogen utilization than the later plantings, but additional nitrogen applied to the crop allowed the advantages of early planting to be more fully expressed than at the low rates. Because the soil in the Elwood study was initially very low in available nitrogen, date of planting without added nitrogen failed to have any effect on yield.

\section{NITROGEN AND OTHER NUTRIENTS}

When a deficiency in one plant nutrient is removed, other added nutrients can often be used more efficiently. Data from a study of nitrogen and potassium rates at DeKalb, Illinois, illustrate this phenomenon (Table 8). Without added potassium, corn yields from 240 pounds of nitrogen per acre (268 kg/ha) rose by only 75 bushels per acre (47 $\mathrm{q} / \mathrm{ha}$ ) over the zero rate, but with 80 pounds of potassium (90 kg/ha) the increase was 85 bushels $(53 \mathrm{q} / \mathrm{ha})$. The higher yield indicates that more nitrogen was taken up by the crop with added potassium than 
Table 8. - Effect of Potassium on Response of Corn to Nitrogen, DeKalb, Illinois, 1972, 1973, 1975

\begin{tabular}{l}
\hline \multicolumn{7}{c}{$\begin{array}{c}\mathrm{K}_{2} \mathrm{O} \text { rate, } \\
\mathrm{lb} / \mathrm{A}(\mathrm{kg} / \mathrm{ha})\end{array}$} \\
\cline { 2 - 8 }
\end{tabular}

without it. As a result, less nitrogen remained in the soil for potential leaching.

\section{NONUNIFORM DISTRIBUTION OF APPLIED NITROGEN}

Nonuniform distribution of nitrogen in the field is yet another factor that can result in reduced yield and hence reduced uptake of nitrogen. In effect, the fertilizer rate varies from one area of a field to the next even though the average rate is kept constant for the field as a whole. Patches of good and poor plant growth may be visible where fertilizer has been applied unevenly. These telltale signs, more obvious for nonuniform spreading of nitrogen than of phosphorus and potassium, are easily detected in small grains, pasture grasses, and lawns.

Sometimes bulk-blended, dry materials of different particle size segregate as the truck or wagon bumps along the field. The smaller particles tend to settle toward the bottom while the larger ones remain at the top. If the large particles are nitrogen and the small ones potassium, more potassium and less nitrogen than desired will be applied at first; the reverse will occur as spreading continues.

Even when fertilizer materials remain uniformly mixed, a spinnertype spreader may throw particles of different sizes unequal distances. Wind may also carry the fertilizer farther to one side than the other of the spreader without the operator's awareness. Even with a uniform mix and no wind, the driver may leave skips or overlaps. Nutrients in liquid fertilizer may precipitate and settle to the bottom, or plugged or worn spray nozzles may put out less or more fertilizer than desired.

Because of diminishing returns, crop yields are lower when fertilizer distribution is uneven. At high rates, the unintended fertilizer increment on some areas of the field has almost no effect on yield increase. It the same time, the other areas of the field receive less than optimum rates. Research agronomists often use different fertilizer rates to determine 
the yield response to added fertilizer. Conditions similar to a research situation are inadvertently created by nonuniform distribution. Therefore, yield response to nonuniform distribution can be predicted from the results of fertilizer rate studies if the degree of unequal distribution is known. In the example that follows, data from the first two columns of Table 7 were used to show how yields from nonuniform distribution are calculated.

Assume that a rate of 180 pounds of nitrogen per acre $(201 \mathrm{~kg} / \mathrm{ha})$ is to be applied uniformly to a 100 -acre field ( 40.5 ha). However, the fertilizer is actually spread so that 50 percent of the field receives 120 pounds per acre (134 kg/ha) and the other 50 percent 240 pounds ( $268 \mathrm{~kg} / \mathrm{ha})$. With uniform application the yield would be 15,400 bushels of corn $(3,909 \mathrm{q})$ for the entire field. With the assumed nonuniform application, the yield is only 14,850 bushels $(3,769 \mathrm{q})$, a difference of 550 bushels $(139 \mathrm{q})$. The decreased yield means that 425 additional pounds of nitrogen $(191 \mathrm{~kg}$ ) remain in the field and might leach before the next cropping season.

\section{Residual Nitrogen Absorbed by Corn}

About 98 percent of the corn grown in Illinois is harvested for the grain only rather than for silage. Added nitrogen not recovered in grain may remain in the field as inorganic nitrogen $\left(\mathrm{NO}_{3}{ }^{-}\right.$or $\mathrm{NH}_{4}{ }^{+}$) or as organic nitrogen in microbial tissue, unharvested stover, and roots. Some of this unharvested nitrogen may leach or denitrify, but some of it may be absorbed by future crops. Although this report is concerned primarily with the nitrogen removed in harvested grain rather than in the entire above-ground plant, the fate of the unharvested nitrogen is important for establishing good management practices that minimize water pollution from nitrogen fertilizer. One method for measuring the availability of this residual or unused nitrogen to future crops is described in the sections that follow.

\section{DEKALB STUDY}

In the first part of a two-phase study at DeKalb, Illinois, nitrogen was added annually to corn from 1965 through 1972 (Table 9). The total amount of nitrogen applied during this eight-year period ranged from zero to 2,880 pounds per acre $(3,240 \mathrm{~kg} / \mathrm{ha})$. In the second part of the study nitrogen applications were completely discontinued on some of the corn plots after 1972, while other plots received 80 and still others 160 pounds of nitrogen per acre (90 and $180 \mathrm{~kg} / \mathrm{ha}$ ) annually during the three-year period from 1973 through 1975 (Mulvaney et al., 1976). 
Table 9. - Effect of Residual and Currently Applied Fertilizer Nitrogen on Corn Yields, DeKalb, Illinois

\begin{tabular}{|c|c|c|c|c|c|c|c|c|c|}
\hline \multirow{3}{*}{$\begin{array}{c}\text { N added } 1965-1972, \\
\mathrm{lb} / \mathrm{A} / \mathrm{yr} \\
(\mathrm{kg} / \mathrm{ha} / \mathrm{yr})\end{array}$} & \multicolumn{9}{|c|}{$\mathrm{N}$ added $1973-1975, \mathrm{lb} / \mathrm{A} / \mathrm{yr}(\mathrm{kg} / \mathrm{ha} / \mathrm{yr})$} \\
\hline & \multicolumn{3}{|c|}{0} & \multicolumn{3}{|c|}{$80(90)$} & \multicolumn{3}{|c|}{$160(180)$} \\
\hline & 1973 & 1974 & 1975 & 1973 & 1974 & 1975 & 1973 & 1974 & 1975 \\
\hline & \multicolumn{9}{|c|}{ Corn yield, bu/A (q/ha) } \\
\hline $0 \ldots \ldots \ldots \ldots$ & $\begin{array}{c}57 \\
(36)\end{array}$ & $\begin{array}{c}40 \\
(25)\end{array}$ & $\begin{array}{c}49 \\
(31)\end{array}$ & $\begin{array}{c}88 \\
(55)\end{array}$ & $\begin{array}{c}79 \\
(50)\end{array}$ & $\begin{array}{l}117 \\
(73)\end{array}$ & $\begin{array}{l}117 \\
(73)\end{array}$ & $\begin{array}{l}107 \\
(67)\end{array}$ & $\begin{array}{l}150 \\
(94)\end{array}$ \\
\hline $\begin{array}{l}80 \ldots \ldots \ldots \ldots \ldots \\
(90) \ldots \ldots \ldots \ldots\end{array}$ & $\begin{array}{c}56 \\
(35)\end{array}$ & $\begin{array}{c}43 \\
(27)\end{array}$ & $\begin{array}{c}53 \\
(33)\end{array}$ & $\begin{array}{l}101 \\
(63)\end{array}$ & $\begin{array}{c}77 \\
(48)\end{array}$ & $\begin{array}{l}129 \\
(81)\end{array}$ & $\begin{array}{l}119 \\
(75)\end{array}$ & $\begin{array}{l}104 \\
(65)\end{array}$ & $\begin{array}{l}153 \\
(96)\end{array}$ \\
\hline $\begin{array}{c}120 \ldots \ldots \ldots \ldots \ldots \\
(135) \ldots \ldots \ldots \ldots\end{array}$ & $\begin{array}{c}69 \\
(43)\end{array}$ & $\begin{array}{c}50 \\
(31)\end{array}$ & $\begin{array}{c}49 \\
(31)\end{array}$ & $\begin{array}{c}94 \\
(59)\end{array}$ & $\begin{array}{c}82 \\
(51)\end{array}$ & $\begin{array}{l}121 \\
(76)\end{array}$ & $\begin{array}{l}122 \\
(76)\end{array}$ & $\begin{array}{l}106 \\
(66)\end{array}$ & $\begin{array}{l}150 \\
(94)\end{array}$ \\
\hline $\begin{array}{r}160 \ldots \ldots \ldots \ldots \\
(180) \ldots \ldots \ldots \ldots\end{array}$ & $\begin{array}{c}63 \\
(40)\end{array}$ & $\begin{array}{l}38 \\
(24)\end{array}$ & $\begin{array}{c}55 \\
(34)\end{array}$ & $\begin{array}{l}101 \\
(63)\end{array}$ & $\begin{array}{c}84 \\
(53)\end{array}$ & $\begin{array}{l}128 \\
(80)\end{array}$ & $\begin{array}{l}123 \\
(77)\end{array}$ & $\begin{array}{l}110 \\
(69)\end{array}$ & $\begin{array}{l}148 \\
(93)\end{array}$ \\
\hline $\begin{array}{r}200 \ldots \ldots \ldots \ldots \ldots \\
(225) \ldots \ldots \ldots \ldots\end{array}$ & $\begin{array}{c}66 \\
(41)\end{array}$ & $\begin{array}{c}51 \\
(32)\end{array}$ & $\begin{array}{c}48 \\
(30)\end{array}$ & $\begin{array}{c}98 \\
(61)\end{array}$ & $\begin{array}{c}84 \\
(53)\end{array}$ & $\begin{array}{l}127 \\
(80)\end{array}$ & $\begin{array}{l}121 \\
(76)\end{array}$ & $\begin{array}{l}109 \\
(68)\end{array}$ & $\begin{array}{l}146 \\
(92)\end{array}$ \\
\hline $\begin{array}{c}240-360 \ldots \ldots \ldots \ldots \\
(270-405) \ldots \ldots \ldots \ldots\end{array}$ & $\begin{array}{c}73 \\
(46)\end{array}$ & $\begin{array}{l}47 \\
(29)\end{array}$ & $\begin{array}{c}53 \\
(33)\end{array}$ & $\begin{array}{l}103 \\
(65)\end{array}$ & $\begin{array}{c}82 \\
(51)\end{array}$ & $\begin{array}{c}129 \\
(81)\end{array}$ & $\begin{array}{l}124 \\
(78)\end{array}$ & $\begin{array}{l}112 \\
(70)\end{array}$ & $\begin{array}{l}148 \\
(93)\end{array}$ \\
\hline
\end{tabular}

- Yields averaged for rates of 240,280 , and 360 pounds per acre $(270,314,405 \mathrm{~kg} / \mathrm{ha})$.

As might be expected, residual nitrogen was more effective the first year, 1973, than in the following two years. On those plots where no nitrogen was added during 1973, 1974, and 1975, residual nitrogen increased corn yields 16,7 , and 4 bushels per acre, respectively (10, 4, and $2 \mathrm{q} / \mathrm{ha}$ ). Also as anticipated, residual nitrogen had a greater effect on yields when no additional nitrogen was applied than when it was added during the second phase of the study. The nitrogen left over in the soil from the highest rates used during the first phase of the study; namely 240 to 360 pounds per acre ( 270 to $405 \mathrm{~kg} / \mathrm{ha}$ ), increased the 1973 corn yield by 16 bushels per acre ( $10 \mathrm{q} /$ ha $)$ with no additional nitrogen. Residual nitrogen increased the 1973 yields 15 and 7 bushels per acre (9 and $4 \mathrm{q} / \mathrm{ha}$ ) on plots that received 80 and 160 pounds of nitrogen in 1973. Although there was some variability in yield increases from residual nitrogen, there was obviously not enough for high corn yields.

Yields from plots that received no nitrogen in 1973 were surprisingly: low, an indication that not much residual nitrogen was available to plants even on those plots where large amounts had been added chring the first eight years of the study. With no nitrogen added in 1973 to the plots that had received the highest rates in the first phase, the yicld was 73 bushels per acre $(46 \mathrm{q} / \mathrm{ha})$. On the other hand, with 80 pounds of nitrogen added to the plots that had not previously been fertilizerl with nitrogen, the yield was 88 bushels per acre ( $55 \mathrm{q} / \mathrm{ha}$ ). This difference in 
yield indicates that residual nitrogen supplied less than the equivalent of 80 pounds of nitrogen per acre for corn in 1973.

In this study only corn grain was harvested; the stover was returned to the soil. During the eight-year period, about 960 pounds of nitrogen per acre $(1,075 \mathrm{~kg} / \mathrm{ha})$ were removed in grain harvested from the plots fertilized annually with 360 pounds of nitrogen per acre. Of the added nitrogen, 1,920 pounds per acre $(2,150 \mathrm{~kg} / \mathrm{ha})$ should have remained in the soil - 2,880 pounds added minus 960 pounds removed. The 1973 corn yields indicate, however, that less than the equivalent of 80 pounds of this amount was available as residual nitrogen. These findings suggest that significant quantities of nitrogen must have been lost by leaching and denitrification.

With no nitrogen added from 1973 through 1975, residual nitrogen from the high-nitrogen plots increased corn yields by a total of only 27 bushels per acre $(17 \mathrm{q} / \mathrm{ha})$ for the entire three-year period. These 27 bushels contained 21 pounds of nitrogen, or 1.1 percent $(21 / 1,920 \times$ 100) of the residual nitrogen that should have been available, but obviously was not, after eight years of heavy fertilization. Apparently most of this nitrogen was lost before 1973. Unlike some Illinois soils, the Drummer silty clay loam at DeKalb does not seem to store nitrogen well.

The DeKalb data indicate that growers would be unwise to add higher rates of nitrogen than the current crop can use: little of the unused nitrogen seems to stay in the soil for future crops. Phosphorus and potassium, by contrast, do not readily leach except in sandy soils and are not lost by processes comparable to denitrification. Nitrogen should be addled annually to minimize losses.

\section{URBANA STUDY}

A residual study, somewhat similar to the one at DeKalb, was conducted at Urbana, Illinois, in 1973 (M.G. Oldham, personal communication). The soil at Urbana is a Drummer silty clay loam much like that at DeKalb. Some of the Urbana plots fertilized at various nitrogen rates between 1968 and 1972 had no nitrogen applied for the 1973 crop; other plots continued to be fertilized at the same rate used during the five preceding years.

Corn yields indicate that some leftover nitrogen was available from the earlier applications (Table 10). Resiclual nitrogen increased yields 30 bushels per acre (19 q/ha) on plots receiving no nitrogen in 1973 but fertilized at the two highest rates (averaged) during the previous five years. Thirty bushels is not, however, a large increase in view of the substantial quantities of residual nitrogen that could have been pres- 


\section{Table 10. - Effect of Residual and Currently \\ Applied Fertilizer Nitrogen on Corn Yields, Urbana, Illinois, 1973}

\begin{tabular}{|c|c|c|}
\hline \multirow[b]{2}{*}{$\begin{array}{l}\mathrm{N} \text { added } 1968-1972, \\
\mathrm{lb} / \mathrm{A} / \mathrm{yr}(\mathrm{kg} / \mathrm{ha} / \mathrm{yr})\end{array}$} & \multicolumn{2}{|c|}{$\mathrm{N}$ added in 1973} \\
\hline & $\begin{array}{l}\text { None, } \\
\text { residual } \\
\text { only }\end{array}$ & $\begin{array}{c}\text { Added at } \\
1968-1972 \\
\text { rates }\end{array}$ \\
\hline & \multicolumn{2}{|c|}{1973 corn yield, bu/A $(q / h a))$} \\
\hline $\begin{array}{r}0 \ldots \\
80(90) \ldots \ldots \ldots \\
160(180) \ldots \ldots \ldots \\
240(270) \ldots \ldots \ldots \\
320(360) \ldots \ldots \ldots\end{array}$ & $\begin{array}{r}59(37) \\
.50(31) \\
.78(49) \\
.92(58) \\
86(54)\end{array}$ & $\begin{array}{r}59(37) \\
119(75) \\
135(85) \\
130(82) \\
144(90)\end{array}$ \\
\hline
\end{tabular}

ent. Yields from the top-producing, residual-only plots were still 30 bushels per acre less than yields from the plot that received the 80-pound rate in 1973. The much higher yields from additional nitrogen in 1973 clearly indicate that lack of added nitrogen limited yields on the residual plots. The Urbana study supports the DeKalb finding that nitrogen cannot be efficiently stored in the soil for extended periods.

\section{OTHER STUDIES}

Unlike the DeKalb and Urbana research, some studies indicate that the soil may indeed store considerable residual nitrogen that is available for plant absorption. Corn yields in a 1978 study on Flanagan silt loam at Urbana were about 150 bushels per acre ( $94 \mathrm{q} / \mathrm{ha}$ ) with no nitrogen added; yields were not increased with added fertilizer nitrogen (unpublished data of R. G. Hoeft and L. F. Welch). In 1976 and 1977 the Flanagan area grew soybeans with no nitrogen fertilizer applied. It is not clear why there was so much available nitrogen present in the 1978 study. However, because of better drainage, denitrification is likely to be less on Flanagan than on Drummer soil.

Westerman and Kurtz (1972) at Urbana found that on Brenton soil the tops of second-year sorghum-Sudan grass contained 13 to 18 percent of the residual nitrogen remaining in the soil one year after nitrogen application and cropping. Uptake of residual nitrogen the second year equaled 4 to 6 percent of the originally applied nitrogen fertilizer.

Unless present in organic form or as ammonium, nitrogen in the soil can leach or denitrify. However, the organic matter, or humus, contained in soil does not build up rapidly. Even with rather large announts of newly added plant material, build-up is very slow because most of the 
Table 11. - Effect of Time of Application and Nitrogen Rate on Continuous Corn Yields at Four Locations in Illinois, 1970-1976

\begin{tabular}{|c|c|c|c|c|c|c|c|c|c|c|}
\hline \multirow{3}{*}{$\begin{array}{l}\mathrm{N}, \mathrm{lb} / \mathrm{A} \\
(\mathrm{kg} / \mathrm{ha})\end{array}$} & \multicolumn{10}{|c|}{ Location and time of $\mathrm{N}$ application } \\
\hline & \multicolumn{2}{|c|}{ Brownstown } & \multicolumn{2}{|c|}{ Carthage } & \multicolumn{2}{|c|}{ Hartsburg } & \multicolumn{2}{|c|}{ Urbana } & \multicolumn{2}{|c|}{ Average } \\
\hline & Fall & Spring & Fall & Spring & Fall & Spring & Fall & Spring & Fall & Spring \\
\hline & \multicolumn{10}{|c|}{ Corn yield, bu/A (q/ha) } \\
\hline $0 \ldots$. & $\begin{array}{c}30 \\
(19)\end{array}$ & $\begin{array}{c}30 \\
(19)\end{array}$ & $\begin{array}{c}31 \\
(19)\end{array}$ & $\begin{array}{c}31 \\
(19)\end{array}$ & $\begin{array}{c}72 \\
(45)\end{array}$ & $\begin{array}{c}72 \\
(45)\end{array}$ & $\begin{array}{c}94 \\
(59)\end{array}$ & $\begin{array}{c}94 \\
(59)\end{array}$ & $\begin{array}{c}57 \\
(36)\end{array}$ & $\begin{array}{c}57 \\
(36)\end{array}$ \\
\hline $\begin{array}{r}60 \ldots \ldots \\
(67) \ldots\end{array}$ & $\begin{array}{c}60 \\
(38)\end{array}$ & $\begin{array}{c}79 \\
(50)\end{array}$ & $\begin{array}{c}62 \\
(39)\end{array}$ & $\begin{array}{c}77 \\
(48)\end{array}$ & $\begin{array}{l}106 \\
(66)\end{array}$ & $\begin{array}{l}112 \\
(70)\end{array}$ & $\begin{array}{l}126 \\
(79)\end{array}$ & $\begin{array}{l}130 \\
(82)\end{array}$ & $\begin{array}{c}88 \\
(56)\end{array}$ & $\begin{array}{l}100 \\
(62)\end{array}$ \\
\hline $\begin{array}{c}120 \ldots \ldots \\
(134) \ldots \ldots\end{array}$ & $\begin{array}{c}82 \\
(51)\end{array}$ & $\begin{array}{c}99 \\
(62)\end{array}$ & $\begin{array}{c}83 \\
(52)\end{array}$ & $\begin{array}{l}110 \\
(69)\end{array}$ & $\begin{array}{l}137 \\
(86)\end{array}$ & $\begin{array}{l}139 \\
(87)\end{array}$ & $\begin{array}{l}132 \\
(83)\end{array}$ & $\begin{array}{l}150 \\
(94)\end{array}$ & $\begin{array}{l}108 \\
(68)\end{array}$ & $\begin{array}{l}124 \\
(78)\end{array}$ \\
\hline $\begin{array}{c}180 \ldots \ldots \\
(201) \ldots\end{array}$ & $\begin{array}{c}95 \\
(60)\end{array}$ & $\begin{array}{l}102 \\
(64)\end{array}$ & $\begin{array}{l}112 \\
(70)\end{array}$ & $\begin{array}{l}130 \\
(82)\end{array}$ & $\begin{array}{l}137 \\
(86)\end{array}$ & $\begin{array}{l}148 \\
(93)\end{array}$ & $\begin{array}{l}149 \\
(93)\end{array}$ & $\begin{array}{l}156 \\
(98)\end{array}$ & $\begin{array}{l}123 \\
(77)\end{array}$ & $\begin{array}{l}134 \\
(84)\end{array}$ \\
\hline $\begin{array}{c}240 \ldots \ldots \\
(268) \ldots .\end{array}$ & $\begin{array}{c}99 \\
(62)\end{array}$ & $\begin{array}{c}96 \\
(60)\end{array}$ & $\begin{array}{l}126 \\
(79)\end{array}$ & $\begin{array}{l}125 \\
(78)\end{array}$ & $\begin{array}{l}153 \\
(96)\end{array}$ & $\begin{array}{l}149 \\
(93)\end{array}$ & $\begin{array}{l}155 \\
(97)\end{array}$ & $\begin{array}{c}160 \\
(100)\end{array}$ & $\begin{array}{l}133 \\
(84)\end{array}$ & $\begin{array}{l}132 \\
(83)\end{array}$ \\
\hline
\end{tabular}

carbon, which "protects" the nitrogen in organic matter, leaves the soil as carbon dioxide as a result of decomposition from microbial activity. Some of the nitrogen released from the added humus may be stored temporarily in organic form in the bodies of microbes responsible for decomposition, but these microbes soon die and the extra nitrogen in their bodies mineralizes, appearing as "unprotected," inorganic forms.

Most cropping systems do not allow humus to accumulate fast enough to store considerable quantities of excess nitrogen. Consequently, large amounts of nitrogen can usually be maintained only for brief periods in soils, such as the Drummer silty clay loams at DeKalb and Urbana, where leaching and denitrification are likely to occur.

\section{Time of Nitrogen Application for Corn}

Evidence predicts that the shorter the time between nitrogen application and absorption by plants, the more efficient the nitrogen should be per unit added. When the time span is relatively short, the added nitrogen has less opportunity to leach and denitrify. Research findings on the relationship between time of application and wheat and corn yields is presented in Welch et al. (1966 and 1971). The discussion that follows presents additional data showing the yield response of corn to various rates of nitrogen applied in the fall and in the spring at six locations in Illinois (Tables 11 and 12). Besides showing the advantage of spring versus fall application, these data may be used to calculate the most profitable rate of nitrogen.

Nitrogen applied to continuous corn led to a threefold yield increase 


\section{Table 12. - Effect of Time of Application and Nitrogen Rate on Average Yields for Continuous Corn at Two Illinois Locations, DeKalb, 1972-1974, and Elwood, 1972-1975}

\begin{tabular}{|c|c|c|c|c|c|c|}
\hline \multirow{3}{*}{$\begin{array}{l}\mathrm{N}, \mathrm{lb} / \mathrm{A} \\
(\mathrm{kg} / \mathrm{ha})\end{array}$} & \multicolumn{6}{|c|}{ Location and time $\mathrm{N}$ applied } \\
\hline & \multicolumn{2}{|c|}{ DeKalb } & \multicolumn{2}{|c|}{ Elwood } & \multicolumn{2}{|c|}{ Average } \\
\hline & Fall & Spring & Fall & Spring & Fall & Spring \\
\hline & \multicolumn{6}{|c|}{ Corn yield, bu/A (q/ha) } \\
\hline $0 \ldots \ldots \ldots \ldots \ldots$ & $\begin{array}{c}64 \\
(40)\end{array}$ & $\begin{array}{c}64 \\
(40)\end{array}$ & $\begin{array}{c}61 \\
(38)\end{array}$ & $\begin{array}{l}61 \\
(38)\end{array}$ & $\begin{array}{c}62 \\
(39)\end{array}$ & $\begin{array}{c}62 \\
(39)\end{array}$ \\
\hline $80 \ldots \ldots \ldots \ldots \ldots$ & $\begin{array}{c}83 \\
(52)\end{array}$ & $\begin{array}{c}96 \\
(60)\end{array}$ & $\begin{array}{c}84 \\
(53)\end{array}$ & $\begin{array}{c}93 \\
(58)\end{array}$ & $\begin{array}{c}84 \\
(52)\end{array}$ & $\begin{array}{c}94 \\
(59)\end{array}$ \\
\hline$(160 \ldots \ldots \ldots \ldots \ldots \ldots$ & $\begin{array}{c}94 \\
(59)\end{array}$ & $\begin{array}{l}110 \\
(69)\end{array}$ & $\begin{array}{c}99 \\
(62)\end{array}$ & $\begin{array}{l}119 \\
(75)\end{array}$ & $\begin{array}{c}96 \\
(60)\end{array}$ & $\begin{array}{l}114 \\
(72)\end{array}$ \\
\hline $\begin{array}{r}240 \ldots \ldots \ldots \ldots \ldots \\
(270) \ldots \ldots \ldots \ldots \ldots\end{array}$ & $\begin{array}{l}107 \\
(67)\end{array}$ & $\begin{array}{l}115 \\
(72)\end{array}$ & $\begin{array}{l}105 \\
(66)\end{array}$ & $\begin{array}{l}122 \\
(76)\end{array}$ & $\begin{array}{l}106 \\
(66)\end{array}$ & $\begin{array}{l}118 \\
(74)\end{array}$ \\
\hline $\begin{array}{r}320 \ldots \ldots \ldots \ldots \ldots \\
(360) \ldots \ldots \ldots \ldots \ldots\end{array}$ & $\begin{array}{l}116 \\
(73)\end{array}$ & $\begin{array}{l}119 \\
(75)\end{array}$ & $\begin{array}{l}106 \\
(66)\end{array}$ & $\begin{array}{l}124 \\
(78)\end{array}$ & $\begin{array}{l}111 \\
(70)\end{array}$ & $\begin{array}{l}122 \\
(76)\end{array}$ \\
\hline
\end{tabular}

at Brownstown, fourfold at Carthage, and twofold at DeKalb, Elwood, and Hartsburg. Because the study at Urbana was started at the present site only in 1974, yields from the zero-nitrogen treatment are high, but are expected to decline with additional years of cropping.

The yield increase was less from nitrogen applied in the fall than from the same amount applied in the spring. To calculate the relative efficiency values of these two times of application, yield increase from fall-applied nitrogen was divided by the increase from spring-applied nitrogen and the value divided by 100 . This calculated value expresses yield increase from fall nitrogen as a percent of the increase from spring nitrogen. A value of 100 percent, for example, would mean that fall and spring nitrogen gave the same yield increase. As the data in Table 13 indicate, nitrogen applied in the fall was considerably inferior to that applied in the spring. At Brownstown, Carthage, DeKalb, and Elwood yield increases from fall applications at the two lowest rates were only about two-thirds of the increase from spring applications. Fall nitrogen performed more efficiently at Hartsburg and Urbana than at the other four locations.

In accord with the usual pattern of diminishing returns, as yiekd increases become smaller at the higher rates of nitrogen, the gap narrowed between yield increases from spring and from fall nitrogen. This tecrease is reflected in the averages for the six locations (Table 13). It very high application rates, considerable nitrogen may be lost with no appreciable effect on yield. 
Table 13. - Yield Increase From Fall-Applied Nitrogen as Percent of Increase From Spring-Applied Nitrogen at Six Locations in Illinois

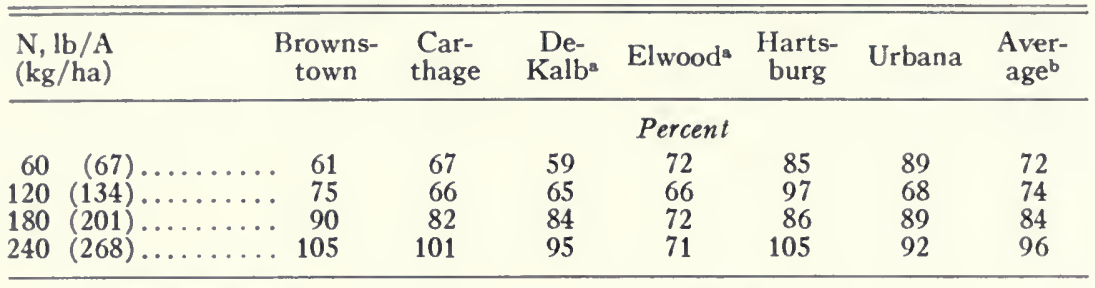

- Nitrogen rates were $80,160,240,320(90,180,270,360 \mathrm{~kg} / \mathrm{ha}$ ).

b Weighted average calculated from data in Tables 11 and 12 .

Although the data do not reflect annual changes, considerable variation in the relative efficiency of fall versus spring nitrogen is apt to occur from year to year as well as from one location to another. In some years, conditions may promote nitrogen loss after fall application on some plots but before the time of spring application on other plots. As a result, fall-nitrogen yields are likely to be lower than spring-nitrogen yields. In other years, conditions may not favor nitrogen loss; consequently, yields from the two times of application will probably be similar. At some research sites, the highest rate of fall nitrogen produced slightly larger yields than spring nitrogen, but this situation is unusual in Illinois. Even though fall-nitrogen yields may occasionally equal those for spring, rarely, and then only by chance, will they exceed springnitrogen yields.

In spite of the obvious advantage of applying nitrogen in the spring, some growers still seriously consider fall application for several reasons. Spring is a busy time on Illinois farms, weather conditions may leave only a few suitable days for early planting, and local dealers may be swamped by growers' demands for fertilizer and application equipment. Planting delays at this crucial time usually lead to reduced yields, a risk that growers can partly avoid by applying nitrogen in the fall. Alternatively, they can sidedress, but this method requires more care and time than fall or spring preplant application.

Spring preplant application is by far the most common method used for corn in Illinois. Nevertheless, fall application is used often enough that care should be taken to limit the amount of potentially leachable nitrogen. Nitrification inhibitors may, however, reduce the amount of nitrogen lost from certain types of fall-applied fertilizers. The use of these chemicals is discussed on pages 40 to 43 of this report. Although the time-of-application studies used ammonium nitrate, 50 percent of 
Table 14. - Soybean Yields (Four-Year Averages) as Affected by Nitrogen Applied to Corn the Preceding Year at Four Illinois Locations

\begin{tabular}{|c|c|c|c|c|c|}
\hline \multirow{2}{*}{$\begin{array}{l}\text { N applied to } \\
\text { corn, lb/A } \\
(\mathrm{kg} / \mathrm{ha})\end{array}$} & \multicolumn{5}{|c|}{ Soybean yield, bu/A (q/ha) } \\
\hline & Aledo & Dixon & Elwood & Kewanee & $\begin{array}{l}\text { Average } \\
\text { for } 4 \\
\text { locations }\end{array}$ \\
\hline $0 \ldots \ldots \ldots \ldots \ldots \ldots$ & $\begin{array}{c}48 \\
(32)\end{array}$ & $\begin{array}{l}40 \\
(27)\end{array}$ & $\begin{array}{l}37 \\
(25)\end{array}$ & $\begin{array}{l}40 \\
(27)\end{array}$ & $\begin{array}{c}41 \\
(28)\end{array}$ \\
\hline $\begin{array}{r}80 \ldots \ldots \ldots \ldots \ldots \ldots \ldots \\
(90) \ldots \ldots \ldots \ldots \ldots \ldots\end{array}$ & $\begin{array}{c}49 \\
(33)\end{array}$ & $\begin{array}{l}40 \\
(27)\end{array}$ & $\begin{array}{l}36 \\
(24)\end{array}$ & $\begin{array}{l}38 \\
(26)\end{array}$ & $\begin{array}{c}41 \\
(28)\end{array}$ \\
\hline $\begin{array}{r}160 \ldots \ldots \ldots \ldots \ldots \ldots \ldots \\
(180) \ldots \ldots \ldots \ldots \ldots \ldots\end{array}$ & $\begin{array}{c}48 \\
(32)\end{array}$ & $\begin{array}{l}39 \\
(26)\end{array}$ & $\begin{array}{l}36 \\
(24)\end{array}$ & $\begin{array}{l}40 \\
(27)\end{array}$ & $\begin{array}{l}41 \\
(28)\end{array}$ \\
\hline $\begin{array}{c}240 \ldots \ldots \ldots \ldots \ldots \ldots \ldots \ldots \ldots \ldots \ldots \\
(270) \ldots \ldots \ldots \ldots \ldots \ldots\end{array}$ & $\begin{array}{c}48 \\
(32)\end{array}$ & $\begin{array}{c}42 \\
(28)\end{array}$ & $\begin{array}{l}36 \\
(24)\end{array}$ & $\begin{array}{l}40 \\
(27)\end{array}$ & $\begin{array}{c}41 \\
(28)\end{array}$ \\
\hline $\begin{array}{r}320 \ldots \ldots \ldots \ldots \ldots \ldots \ldots \ldots \ldots \\
(360) \ldots \ldots \ldots \ldots \ldots \ldots \ldots\end{array}$ & $\begin{array}{c}48 \\
(32)\end{array}$ & $\begin{array}{l}42 \\
(28)\end{array}$ & $\begin{array}{l}36 \\
(24)\end{array}$ & $\begin{array}{l}37 \\
(25)\end{array}$ & $\begin{array}{l}41 \\
(28)\end{array}$ \\
\hline
\end{tabular}

which is leachable without bacterial transformation, an all-ammonium dry source such as urea does not appear to give any additional yield advantage (Figure 9). Theoretically, anhydrous ammonia should perform better than urea and ammonium nitrate when applied in the fall, since ammonia retards nitrification.

Proper time of application is a management practice that may increase nitrogen efficiency and also lower the potential for leaching into wells, rivers, lakes, and underground reservoirs. These studies do not indicate whether the less efficient, fall-applied nitrogen was lost by leaching, denitrification, or both. If due to leaching, the loss could affect water quality while denitrification would not.

\section{Time of Application to Soybeans}

Soybean yields apparently are not affected by extra soil nitrogen or by residual fertilizer, according to findings presented in an earlier section of this report. Further evidence for this conclusion is presented in Tables 14 to 16 (Welch et al., 1973). Some of the amounts of nitrogen applied to corn at four locations with a corn-soybean rotation were greater than would normally be removed by the corn crop. Nevertheless, any nitrogen that may have remained in the soil did not increase yields of the soybean crop that followed (Table 14).

A surplus of soil nitrogen reduces the activity of nitrogen-fixing bacteria. If, however, nitrogen were to be applied after root nodules are well established, then perhaps nitrogen-fixing bacteria would remain active. With the plant using both symbiotic and fertilizer nitrogen 
Table 15. - Effect of Nitrogen Rate and Time of Application on Soybean Yields, Urbana, Illinois

\begin{tabular}{|c|c|c|c|}
\hline $\begin{array}{l}\mathrm{N}, \mathrm{lb} / \mathrm{A} \\
(\mathrm{kg} / \mathrm{ha})\end{array}$ & $\begin{array}{c}\text { Date } \\
\text { applied }\end{array}$ & Plant stage & $\begin{array}{l}\text { Yield, } \\
\text { bu/A } \\
\text { (q/ha) }\end{array}$ \\
\hline $\begin{array}{r}0 \\
100(112) \\
200(224)\end{array}$ & $\begin{array}{l}\text { June } 20 \\
\text { June } 20\end{array}$ & $\begin{array}{l}\text { Early flowering } \\
\text { Early flowering }\end{array}$ & $\begin{array}{ll}46 & (31) \\
45 & (30) \\
48 & (32)\end{array}$ \\
\hline $\begin{array}{r}0 \ldots \\
100(112) \\
200(224)\end{array}$ & $\begin{array}{l}\text { July } 12 \\
\text { July } 12\end{array}$ & $\begin{array}{l}\text { Pod filling } \\
\text { Pod filling }\end{array}$ & $\begin{array}{ll}46 & (31) \\
46 & (31) \\
47 & (32)\end{array}$ \\
\hline
\end{tabular}

Table 16. - Soybean Yields With Four

Foliar Applications of Nitrogen, Urbana, Illinois, 1976

\begin{tabular}{|c|c|c|}
\hline \multirow{2}{*}{$\begin{array}{l}\mathrm{N} \text { per spraying, } \\
\mathrm{lb} / \mathrm{A}(\mathrm{kg} / \mathrm{ha})^{\mathrm{a}}\end{array}$} & \multicolumn{2}{|c|}{ Variety } \\
\hline & Corsoy & Amsoy \\
\hline & \multicolumn{2}{|c|}{ Yield, bu/A (q/ha) } \\
\hline $\begin{array}{l}0 \ldots \ldots \\
10(11) \ldots \ldots \\
20(22) \ldots . .\end{array}$ & $\begin{array}{ll}58 & (39) \\
56 & (38) \\
55 & (37)\end{array}$ & $\begin{array}{ll}56 & (38) \\
58 & (39) \\
52 & (35)\end{array}$ \\
\hline
\end{tabular}

extensively, perhaps yields would increase. Research at Urbana did not support this hypothesis: nitrogen applied to the soil during early flowering and during pod filling had no effect on yields (Table 15).

Because soybean grain contains so much nitrogen (about 6.5 percent), the plant organ that produces seed must have a plentiful supply of nitrogen available during grain development. This supply normally comes from the roots, which absorb nitrogen from the soil and harbor nitrogen-fixing bacteria. Some nitrogen previously stored in the vegetative parts of the plant is also translocated to grain. Any factor that hinders top-level performance by roots and bacteria will also depress yields. If roots and bacteria are not doing their job as effectively as possible, yields now considered to be maximum for a particular variety under nearly ideal growing conditions might perhaps be appreciably improved by foliar application of nitrogen.

This hypothesis was tested at Urbana by spraying plants four times beginning with early grain development and then at 12-day intervals at the nitrogen rates indicated in Table 16 . Results show that spraying did 
not increase soybean yields. A reasonable conclusion seems to be that the roots and bacteria were performing adequately; otherwise, foliar application would have led to improved yields.

Spraying did cause some visible damage to the leaves at both the 10and the 20 -pound nitrogen rates ( 11 and $22 \mathrm{~kg} / \mathrm{ha}$ ). Most of the damage was noticeable within three days after the first spraying. The smaller treatment damaged an estimated 5 percent and the larger treatment 13 percent of the upper-leaf area. From this study, as well as from more extensive research reported elsewhere (Welch, 1977), it appears that foliar application of nitrogen to soybeans is not promising.

Soybeans characteristically absorb nitrogen from the soil before drawing on symbiotic fixation as a major source of nitrogen. They are good scavengers for soil nitrogen that might otherwise leach, but because fertilizer nitrogen whether directly applied or residual has not increased soybean yields, adding nitrogen to soybeans in Illinois is an unwise use of resources. Similarly, legumes such as alfalfa and clovers do not benefit from added nitrogen, as other studies have indicated (Mays, 1974).

\section{CHEMICAL METHODS OF CONSERVING FERTILIZER NITROGEN}

Maintaining nitrogen in a "protected" form until shortly before it is to be absorbed by plants is desirable for both economic and environmental reasons. In such a form, nitrogen efficiency would undoubtedly rise and the potential for leaching decline. Several methods that promote the slow release of nitrogen into the soil solution have been tried with varying degrees of success (Prasad et al., 1971).

Using compounds of nitrogen that dissolve very slowly in water is one way to retard leaching. Certain chemical compounds such as oxamides and urea-formaldehydes have proverl somewhat effective. Urea coated with sulfur, thus functioning as a time capsule, has also been used. Although effective on lawns and golf courses, these slowly soluble compounds are costly and therefore not usually practical for use on field crops. Furthermore, field research has shown that in many cases sucl compounds fail to conserve nitrogen.

Another approach is to use nitrogen in a water soluble yet "protected" form and to maintain it in this form until the crop needs it. Ammonium combined with chemicals designed to inhibit nitrification lias been used for this purpose. The sections that follow discuss the chemical control of nitrification, ammonium versus nitrate use by corn, and yield trials with nitrification inhibitors. 


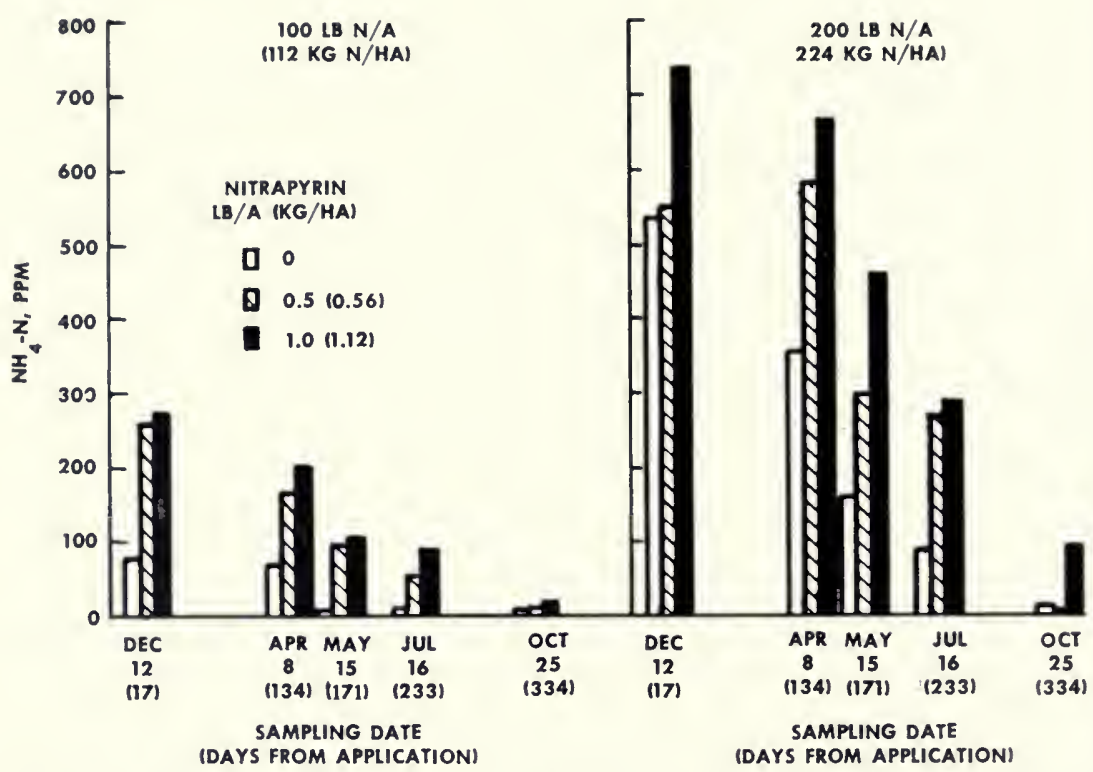

Figure 14. Soil ammonium-nitrogen $\left(\mathrm{NH}_{4}-\mathrm{N}\right)$ concentrations as affected by nitrapyrin, nitrogen rate, and number of days elapsed between application of anhydrous ammonia $\left(\mathrm{NH}_{3}\right)$ on November 25 and sampling date.

\section{Nitrification Inhibitors}

Bacterial activity converts ammonium to nitrite $\left(\mathrm{NO}_{2}^{-}\right)$and then to nitrate $\left(\mathrm{NO}_{3}^{-}\right)$. The function of chemical inhibitors is to slow down this activity and thereby decrease the rate of nitrification. Tests have been run on various chemicals to determine their ability in this regard (Alexander, 1965; Prasad et al., 1971). Preliminary studies of nitrapyrin were made in Illinois more than a decade ago (Sabey, 1968). Nitrapyrin, or 2-chloro-6-(trichloromethyl) pyridine, is marketed under the trade name N-Serve (Dow Chemical Company, Midland, Michigan).

In subsequent research Hughes and Welch (1970) found that nitrapyrin inhibited the nitrification of fall-applied anhydrous ammonia (Figure 14). Without nitrapyrin essentially all ammonium applied on November 25 at the rate of 100 pounds per acre $(112 \mathrm{~kg} / \mathrm{ha})$ had nitrified by May 15, but with 1 pound of nitrapyrin added per acre about 100 parts per million of the ammonium remained in the sampling zone. Still more recently Touchton et al. (1978a and 1978b) reported that nitrapyrin with anliydrous ammonia and urea inhibited nitrification.

Enough research has been conducted to establish that certain chemicals do delay nitrification. This research does not, however, demonstrate 


\section{Table 17. - Corn Stover Yield With Three Rates of Potassium and Either Nitrate, Ammonium, or Ammonium Plus Nitrapyrin, Greenhouse Study}

\begin{tabular}{|c|c|}
\hline Soil treatment & $\begin{array}{l}\text { Grams of } \\
\text { stover } \\
\text { per pot }\end{array}$ \\
\hline $\begin{array}{l}\mathrm{NO}_{3}+80 \text { ppm K... } \\
\mathrm{NO}_{3}+160 \text { ppm K. } \\
\mathrm{NO}_{3}+320 \text { ppm K. }\end{array}$ & $\begin{array}{l}\ldots 27.7 \\
\therefore \quad 26.7 \\
\ldots \quad 28.3\end{array}$ \\
\hline $\begin{array}{l}\mathrm{NH}_{4}+80 \text { ppm K. } \\
\mathrm{NH}_{4}+160 \mathrm{ppm} \mathrm{K} . \\
\mathrm{NH}_{4}+320 \text { ppm K. }\end{array}$ & $\begin{array}{l}\ldots \quad 29.2 \\
\ldots \quad 29.7 \\
\ldots \quad 34.3\end{array}$ \\
\hline $\begin{array}{l}\mathrm{NH}_{4}+\text { nitrapyrin }- \\
\mathrm{NH}_{4}+\text { nitrapyrin } \\
\mathrm{NH}_{4}+\text { nitrapyrin }\end{array}$ & $\begin{array}{l}\ldots 19.2 \\
\ldots \quad 20.4 \\
\ldots 33.5\end{array}$ \\
\hline
\end{tabular}

that they will lead to improved corn yields or to a reduction in the amount of nitrate leaving fields in drainage water. Nitrogen in the form of nitrate is not inevitably lost, but may be if soil and climatic conditions favor leaching and denitrification. Under some circumstances nitrate will remain in the soil and be available for plant uptake. Only through field trials can the effect of nitrification inhibitors on nitrogen conservation and crop yields be shown.

\section{Ammonium Versus Nitrałe Use by Corn}

Using nitrification inhibitors would be of little practical value if keeping nitrogen in the ammonium form reduced nitrogen uptake and hence limited plant growth. In greenhouse studies nitrapyrin and different sources of added nitrogen were used to manipulate the form available for absorption by corn (Dibb and Welch, 1976). Plants grown with added ammonium and nitrapyrin absorbed an estimated 95 percent of their nitrogen as ammonium, but in the preliminary studies the leaves were damaged and yields decreased.

Tests were also conducted using three rates of potassium combined with treatments of nitrate, ammonium, or ammonium plus nitrapyrin (Table 17). In these tests ammonium without nitrapyrin was soon converted to nitrate. At the low levels of potassium ( 80 and $160 \mathrm{p}$ [m ammonium plus nitrapyrin led to reduced corn stover yields. At the highest level $(320 \mathrm{ppm})$, yields for all three nitrogen treatments were about the same. For the nitrate and ammonium treatments without nitrapyrin, the rate of potassium had no significant effect on plant growth. 
For the ammonium-nitrapyrin treatment, however, the rate of potassium made a considerable difference. The findings suggest that keeping nitrogen in the ammonium form may have caused the ammonium and the potassium cations to compete for absorption by the corn plants. At the low levels of potassium, plant growth was retarded, while at the high level potassium became sufficiently competitive so that the plants' need for potassium was fulfilled. Corn can apparently be grown with ammonium as the primary source of nitrogen without growth being adversely affected. However, the nitrogen that is usually absorbed as an anion $\left(\mathrm{NO}_{3}{ }^{-}\right)$would instead be absorbed as a cation $\left(\mathrm{NH}_{4}{ }^{+}\right)$.

The mobility of ammonium and nitrate in the soil may also be important in plant absorption; nitrate is classified as mobile and ammonium as immobile. The reduced mobility of nitrogen kept as ammonium may prevent adequate amounts of nitrogen from moving to the roots and thus being in a position to be absorbed. Mobility was not a factor in the Dibb and Welch greenhouse study, because roots proliferated throughout the entire soil volume.

Results of this study indicate that corn can effectively use nitrogen supplied primarily as ammonium. Nitrification inhibitors can thus be judged on their ability to conserve nitrogen without concern about possible negative effects on plant nutrition.

\section{Yield Trials With Nitrapyrin}

Nitrapyrin clearly delays nitrification and does not hurt plant nutrition, but does it actually increase crop yields? Field trials have been conducted to answer this question. According to research reported by Swezey and Turner (1962), yields from irrigated cotton, sweet corn, and sugar beets increased when nitrapyrin was used with several ammoniacal fertilizers and urea. Research accelerated about the time nitrapyrin was approved by the government for certain crops, but results are not clear-cut because conditions must first favor leaching and denitrification before nitrapyrin can affect yields. If winter and spring are very wet, for example, nitrapyrin will probably improve corn yields. Nitrapyrin can also be used to advantage in coarse-textured soils, where leaching is more common than in fine soils. Also, nitrapyrin may sometimes be indicated for fine-textured soils, which tend to become anaerobic when waterlogged, a condition that encourages losses following denitrification.

In one Indiana study, corn yield increases were large when anhydrous ammonia plus nitrapyrin was applied in the fall to fine sandy loam and sancly clay loam soils (Warren et al., 1975). Other studies in 
Indiana showed average increases of 16 bushels per acre ( $10 \mathrm{q} / \mathrm{ha})$ with fall application at seventeen locations during four years, and 5 bushels per acre ( $3 \mathrm{q} / \mathrm{ha}$ ) with spring application at twenty-two locations during two years (Huber et al., 1977). As these findings suggest, nitrapyrin is more apt to be helpful when added considerably before rapid uptake rather than at the beginning of the planting season. Nitrapyrin with both fall- and spring-applied nitrogen also increased wheat yields.

Research results in states other than Indiana have generally not been promising. Corn yields in a Georgia study did not increase when nitrapyrin was added with fall or spring-preplant anhydrous ammonia to loamy sand (Boswell, 1977). Similar results were obtained in Wisconsin (Walsh, 1977). It is assumed that nitrapyrin did not appreciably reduce nitrogen losses when no crop yield increase was obtained.

The following is a summary of nitrapyrin experiments conducted at several locations in Illinois:

- Inconsistent yield increases with anhydrous ammonia applied in spring and fall at Belleville in 1970 and 1971 (Kapusta and Varsa, 1972)

- No increases with anhydrous ammonia at economically optimal rates applied during different seasons at Brownstown, Urbana, and DeKalb in 1975 and 1976 (Touchton et al., 1978c)

- Some increases with fall-applied urea at the rate of 60 pounds per acre $(67 \mathrm{~kg} / \mathrm{ha})$ in 1976; no increases at economically optimal rates at Brownstown, Urbana, and DeKalb (Touchton et al., 1978b)

It should be pointed out that soil moisture conditions during 1975 and 1976 at Brownstown, Urbana, and DeKalb were not highly favorable to nitrogen losses.

Exactly how effective nitrapyrin will prove to be in conserving nitrogen and cutting down on nitrate in drainage water will become clearer as data accumulate from ongoing studies in Illinois and many other states. Meanwhile, some Illinois growers will continue to use nitrapyrin as a form of insurance, especially with nitrogen applied in the fall for corn.

\section{LEACHING AND DENITRIFICATION STUDIES}

Everyone is directly or indirectly affected when nitrogen applied to crops is lost before it can do its work effectively. When scientists learn more about how nitrogen leaches and denitrifies before plants can use it and what to do to prevent this loss, growers, environmentalists, and consumers alike will benefit. In the two sections that follow, the processes involved in leaching and denitrification are examined in greater detail than in the previous sections of this report. 


\section{Nitrogen Leaching in Soils}

The commonly used inorganic nitrogen fertilizers dissolve very easily in water, a characteristic that is both desirable and undesirable. Its solubility allows nitrogen in the nitrate form to be readily available for plant uptake but also to be leached from fields in drainage water. Nitrogen follows water movement; if this movement is upward because of evaporation from the soil surface, the dissolved nitrogen will also rise toward the surface. On the other hand, if water soaks deep into the soil during heavy rainfall, nitrogen may be carried beyond the roots. It is then lost for purposes of plant nutrition and may eventually seep into water supplies for humans and livestock.

From the considerable volume of research on nitrogen leaching, we know that heavy leaching occurs with excessive rainfall or irrigation; light leaching occurs with scanty rainfall. Even so, workable equations expressing the quantitative relationship between rainfall and leaching have not been developed or applied. Factors other than the amount of rain also affect leaching, for example, the intensity of the rain, the amount of water initially in the soil, the water-holding capacity of soils with different textures and types of clay, the concentration and form of nitrogen in the soil, and the proportion of rain filtering into the soil to that leaving the field as surface runoff.

\section{NITROGEN IN TILE DRAINAGE}

Early Illinois settlers found millions of nitrogen-rich acres of land, but the soil in many parts of the state frequently stayed waterlogged until late in the spring. Because too much moisture as well as too little can create cropping problems, farmers began to install drain tiles beneath their fieldis as early as the late nineteenth century to drain excess

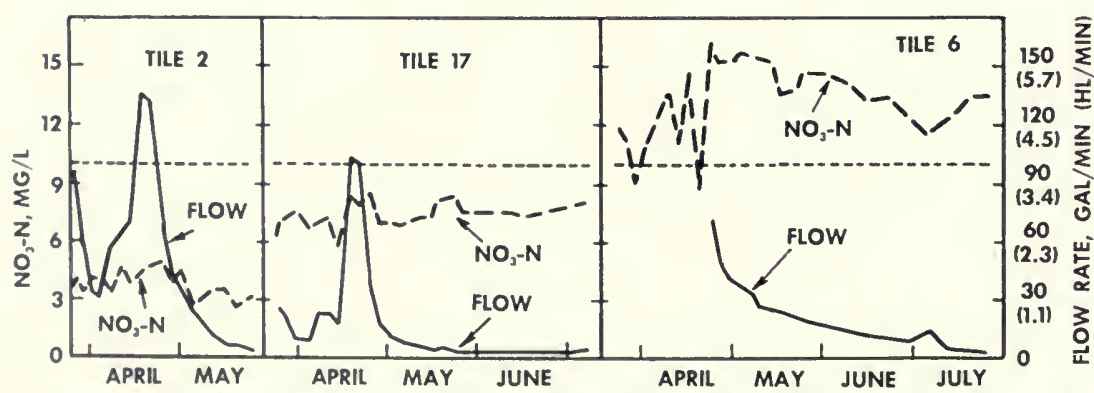

Figure 15. Flow rate and concentration of nitrate-nitrogen in water from tiles draining farmers' fields in Champaign County. The dotted line represents the $10-\mathrm{mg} / \mathrm{l}$ nitrate-nitrogen standard of the U.S. Public Health Service. 


\section{Table 18. - Estimates of Nitrate-Nitrogen Leaching \\ From Soil Through Drain Tiles Into Streams During Years of Low, Normal, and High Rainfall, Champaign County, Illinois}

\begin{tabular}{|c|c|c|c|c|}
\hline & \multirow{2}{*}{$\begin{array}{c}\mathrm{NO}_{3-} \mathrm{N} \\
\text { in tile } \\
\text { water, } \mathrm{mg} / \mathrm{l}\end{array}$} & \multicolumn{3}{|c|}{$\begin{array}{c}\mathrm{NO}_{3-} \mathrm{N} \text { entering stream } \\
\text { from soil, } \mathrm{lb} / \mathrm{A} / \mathrm{yr} \\
(\mathrm{kg} / \mathrm{ha} / \mathrm{yr})\end{array}$} \\
\hline & & $\begin{array}{l}\text { Low } \\
\text { rainfall } \\
\text { year }\end{array}$ & $\begin{array}{l}\text { Normal } \\
\text { rainfall } \\
\text { year }\end{array}$ & $\begin{array}{l}\text { High } \\
\text { rainfall } \\
\text { year }\end{array}$ \\
\hline Lowest tile....... & . 3.0 & $\begin{array}{l}2.3 \\
(2.6)\end{array}$ & $\begin{array}{l}3.2 \\
(3.6)\end{array}$ & $\begin{array}{c}4.8 \\
(5.4)\end{array}$ \\
\hline Highest tile. ..... & . 13.7 & $\begin{array}{l}10.5 \\
(11.8)\end{array}$ & $\begin{array}{l}14.8 \\
(16.6)\end{array}$ & $\begin{array}{l}21.9 \\
(24.5)\end{array}$ \\
\hline $\begin{array}{l}\text { Average of all tiles } \\
\text { study........... }\end{array}$ & $\stackrel{\text { in }}{. .} 10.0$ & $\begin{array}{c}7.7 \\
(8.6)\end{array}$ & $\begin{array}{l}10.8 \\
(12.1)\end{array}$ & $\begin{array}{l}16.0 \\
(17.9)\end{array}$ \\
\hline
\end{tabular}

water from the soil. The drainage water from these tiles flows into submains and mains, and is eventually discharged into drainage ditches, streams, ponds, and the like.

To determine if water leaving farmland through the drainage system is a source of nitrate-nitrogen pollution, water from farmers' fields in Champaign County, Illinois, was sampled for three years at a number of discharge sites and measured for nitrate-nitrogen concentrations. Figure 15 shows these concentrations in water collected from tiles number 2,6 , and 17. Water from tile 2 contained only about 3 milligrams per liter of nitrate-nitrogen, which is well below the public health standard of 10 $\mathrm{mg} / \mathrm{l}$. Concentrations in water from both tile 6 and tile 17 remained fairly constant during the sampling period. Interestingly, the flow rate of these two tiles increased four to six times from early to mid-April, but with almost no corresponding change in the nitrate level. Water from tile 6, which had concentrations higher than any other tile in the study, averaged $14 \mathrm{mg} / \mathrm{l}$, exceeding the public health standard at all but two sampling dates.

In Champaign County roughly an eighth of the average annual rainfall passes through the soil and later enters streams. Thus $3.4,4.8$, and 7.1 inches $(8.6,12.1$, and $17.9 \mathrm{~cm})$ of rain from a low, normal, and high annual rainfall, respectively, will become drainage water (Walton, 1965). These values plus the average nitrate-nitrogen concentrations from the three-year study of tile water were used to calculate how much nitrate leaves each acre of land every year (Table 18). The amount varies from 2.3 pounds per acre $(2.6 \mathrm{~kg} / \mathrm{ha})$ for the tile water with the lowest 


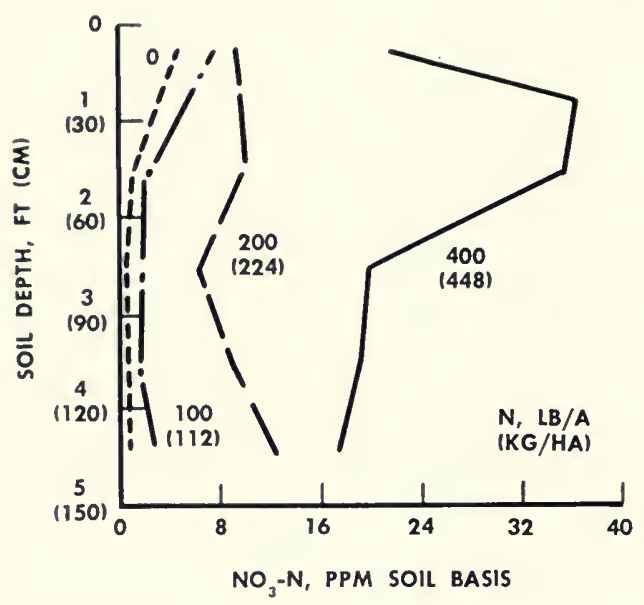

Figure 16. Nitrate-nitrogen in Drummer soil on November 11. Nitrogen, at the rates indicated, had been applied to continuous corn in the fall of the three preceding years.

concentration in a low-rainfall year to 21.9 pounds per acre $(24.5 \mathrm{~kg} / \mathrm{ha})$ at the highest concentration in a high-rainfall year. At the average concentration for all tiles in the study during a year of normal rainfall, 10.8 pounds of nitrate-nitrogen $(12.1 \mathrm{~kg} / \mathrm{ha})$ will leach from one acre.

Because most drainage systems, particularly the older ones, are not adequately mapped, tracing the tiles and hence the areas drained by them is difficult. For this reason the cropping history of the land associated with various tile lines in the study could not be determined. Nevertheless, from what is known about the behavior of nitrogen in the soil, heavily fertilized fields can be expected to leach more nitrate-nitrogen through drainage water than those fertilized at a low rate. Data in the section that follows support this statement.

\section{NITROGEN MOVEMENT WITH CONTINUOUS CORN}

In a three-year experiment at Urbana, four rates of fertilizer nitrogen, namely, 0, 100, 200, and 400 pounds per acre $(0,112,224,448$ $\mathrm{kg} / \mathrm{ha}$ ), were applied in the fall to continuous corn (Bombke, 1972). Following corn harvest, the soil was sampled to a depth of 5 feet (150 $\mathrm{cm}$ ) to determine the nitrate-nitrogen concentration. As the rate of application increased, the nitrate-nitrogen content throughout the soil profile also increased (Figure 16). During the three-year period considerable nitrogen had leached from the plow layer to lower depths in this well-drained soil. At the 100-pound rate applied annually soil nitrogen increased only slightly, but at 400 pounds the increase was large.

Note that in Figures 16 and 17 nitrate-nitrogen content is expressed 


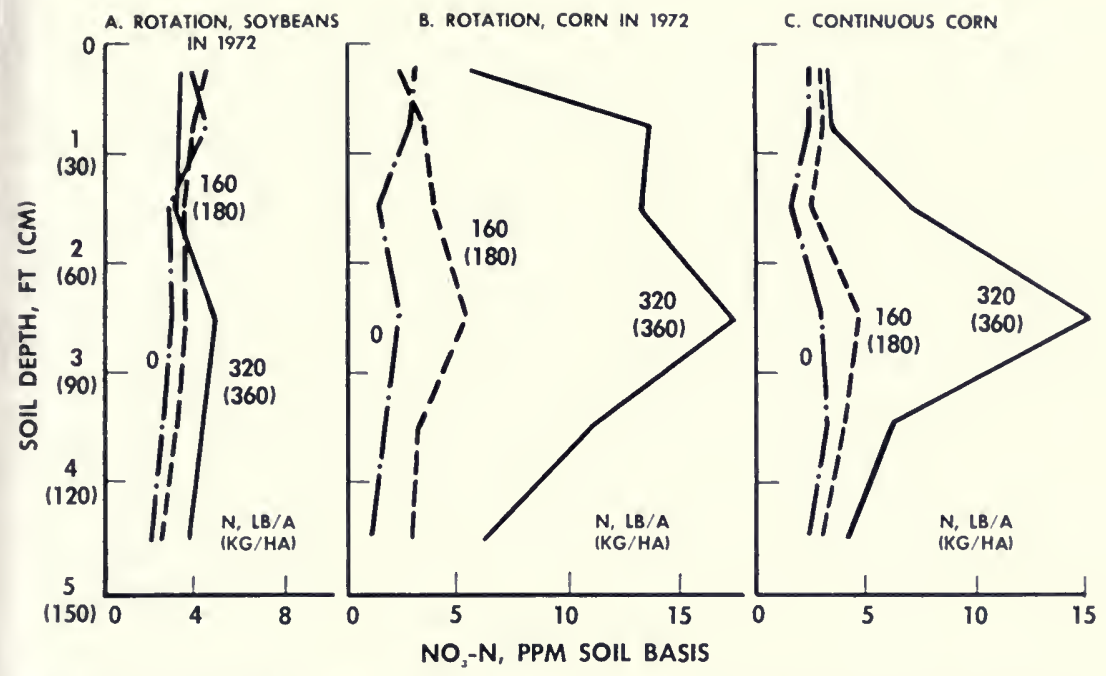

Figure 17. Nitrate-nitrogen in the soil of plots planted to continuous corn and corn-soybeans in a two-year rotation, Elwood, Illinois. Nitrogen was added only for corn at the rates indicated. Soil was sampled May 12, 1972.

on a soil basis; on the basis of soil water the values would be higher. Thus, in a saturated soil presumed to contain 40 percent water, when the soil content is $10 \mathrm{ppm}$, the soil water content will be $25 \mathrm{ppm}$, or $25 \mathrm{mg} / 1$.

These data are not surprising: when far more fertilizer nitrogen is applied than the corn crop needs, marked leaching can be expected. Although Illinois farmers virtually never apply 400 pounds of nitrogen per acre, the data dramatize the results of faulty practices such as using excessive rates.

\section{NITROGEN MOVEMENT WITH CONTINUOUS CORN VERSUS CORN-SOYBEANS}

During recent years in Illinois, soybean acreage has been about 75 to 80 percent as great as corn acreage. Corn sometimes follows corn, but in many areas of the state corn follows soybeans in a two-year rotation. Because nitrogen is usually added for corn but rarely for soybeans, the land with continuous corn probably receives twice as much nitrogen as the rotation land over a period of several years. To determine the distribution of nitrate in the soil profile for these two cropping systems, plots were sampled at Elwood, Illinois, where continuous corn and corn-soybean experiments had been conducted since 1965. At the time the soil was sampled on May 12, 1972, the continuous corn plots and 1971 corn in the corn-soybean rotation had received no nitrogen since spring of 
1971. Corn-soybean plots on which soybeans were grown in 1971 had not been fertilized with nitrogen since spring of 1970 .

The downward movement of nitrates in plots that had received 320 pounds of nitrogen per acre $(360 \mathrm{~kg} / \mathrm{ha})$ is striking. More nitrogen remained in the soil after rotation corn than after continuous corn (Figure 17B and C). However, the soybean crop that followed corn reduced the nitrate level throughout the soil profile, even at the highest rate applied to corn the year before (Figure 17A). The results of these soil samples are yet another indication that soybeans effectively remove residual nitrogen that would otherwise leave the field in drainage water. Soybeans are an especially good scavenger crop when excessively high rates of nitrogen have been applied to corn. Bombke (1972) presents more detailed data on nitrogen movement with various nitrogen rates used at other locations in Illinois.

\section{Denitrification}

From the environmental point of view, leaching is a far greater problem than denitrification. Considered economically, however, denitrification is also troublesome, particularly now that fertilizer nitrogen has become so costly. Before discussing research related to denitrification, let us briefly review nitrification and denitrification, two phases of the nitrogen cycle (Figure 1). Nitrogen in the ammonium form $\left(\mathrm{NH}_{4}{ }^{+}\right)$ contains no oxygen. Through the process of nitrification oxygen is added to these forms but only when enough oxygen is present in the soil. Other forms such as nitrate $\left(\mathrm{NO}_{3}{ }^{-}\right)$are already oxidized but may have the oxygen removed when the supply of oxygen in the soil is low. During this breakdown of oxidized forms, gases such as $\mathrm{NO}, \mathrm{N}_{2} \mathrm{O}$, and $\mathrm{N}_{2}$ are produced and the nitrogen then escapes into the atmosphere. This breakdown with the subsequent loss of nitrogen is called denitrification.

Denitrification, which is a bacterial process, occurs more readily in wet soil than in dry soil. Air and water in an inverse relationship fill the pores between soil particles; that is, pores filled mostly with water will contain little air and vice versa. In waterlogged soils, denitrifying bacteria must get the oxygen they need from oxidized forms of nitrogen. Soil that is both warm and wet is far more favorable to bacterial activity and to the rapid loss of nitrogen present as nitrate than soil that is warm and dry, cold and wet, or cold and dry.

The amount of nitrogen lost by denitrification is difficult to measure because trapping gaseous nitrogen as it escapes from the soil is a prob- 
lem. Many researchers have measured easily-determined forms of nitrogen, but what becomes of the nitrogen not accounted for is a matter of considerable uncertainty. Owens (1960), for example, in a two-year experiment at Urbana grew corn with 120 pounds of nitrogen per acre (134 kg/ha) added annually. He then measured the nitrogen that had been leached, taken up in the corn, and left in the soil. To measure the amount of nitrogen that leached, he used lysimeters to a depth of 38 inches $(96 \mathrm{~cm})$. A lysimeter is a device used to measure the amount of water that drains through soils and from which soluble constituents removed in the drainage can be determined. At the end of two years Owens found that, depending on the water rates, between 5 and 20 percent of the applied nitrogen had leached. About 33 percent, however, was unaccounted for, and he concluded that it had been denitrified.

Moisture content and soil temperature are only two of many factors that influence denitrification. The depth at which a natric horizon (a layer of exchangeable sodium) may be present in the soil is important, because layers having a high sodium content impede the downward movement of water and therefore of dissolved nitrate through the soil. Water in soil with a shallow natric horizon is temporarily trapped on or near the soil surface in an environment suitable for the activity of denitrifying bacteria. When the horizon is deep, however, these bacteria are far less active, so nitrates are more apt to be leached than denitrified.

The relationship between the natric horizon, denitrification, and leaching was investigated by Gentzsch et al. (1974). Earlier studies had indicated that water in almost three-fourths of 213 dug wells sampled in Washington County, Illinois, exceeded the public health standard of $10 \mathrm{mg} / 1$ of nitrate-nitrogen. Gentzsch et al. first measured nitratenitrogen in soil samples, which were classified by depth to the natric horizon and by the presence or absence of an identifiable animal or fertilizer source of nitrogen. Soils receiving less than 71 pounds of fertilizer nitrogen per acre $(80 \mathrm{~kg} / \mathrm{ha})$ were not considered as having a fertilizer source. All soils were poorly drained.

In this phase of their investigation Gentzsch $c t$ al. were primarily concerned with the nitrate concentration in soils below a depth of 3 feet $(90 \mathrm{~cm})$ and in water at the depth of the water table. They found that soils having an intermediate, deep, or no natric horizon contained about seven times more nitrate with a fertilizer source of nitrogen than with no source; those with an animal source contained three to four times more nitrate than soils with a fertilizer source. Water sampled from soils having intermediate to deep natric horizons contained an average of $4.4 \mathrm{mg} / \mathrm{l}$ of nitrate-nitrogen with no identifiable source of nitrogen 
Table 19. - Influence of Natric Horizon and Nitrogen Source on Nitrate-Nitrogen Content of Water Sampled From Water Table

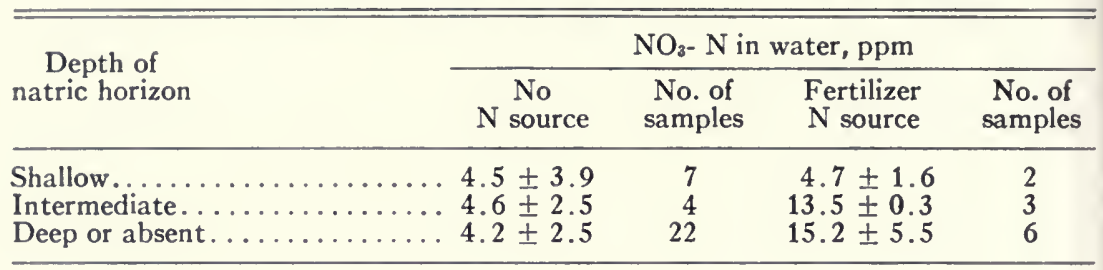

and $14.4 \mathrm{mg} / 1$ with a fertilizer source; $4.7 \mathrm{mg} / 1$ for shallow horizons with a fertilizer source, and $4.5 \mathrm{mg} / \mathrm{l}$ with no source (Table 19).

A layer of readily exchangeable sodium promotes the separation of aggregates of soil into particles that pack tightly and reduce the rate of water infiltration. These conditions in turn promote rapid denitrification in surface soils, which is probably why nitrate concentrations are low when the natric horizon is shallow and high when it is deep. From their research Gentzsch et al. concluded that increasing the fertilizer rates on Washington County soils having intermediate or deep natric horizons is likely to increase the amount of nitrate below the rooting zone. Excess nitrate would tend to leach, thus jeopardizing the water supply in shallow dug wells. Dickey and Lembke (1978), however, found that animal manure and human septic tanks rather than nitrogen fertilizers were the source of high nitrate-nitrogen concentrations in wells.

Unlike natric horizons, which occur only in some soils, the horizons discussed in the section that follows are designations common to all soils and refer to the different materials found in various layers of the soil profile. McKenzie and Kurtz (1976) studied denitrification in samples from six horizons of Drummer silty clay incubated in the laboratory. The topmost horizon contained 6.0 percent organic matter, while the deepest at 45 to 48 inches ( 114 to $122 \mathrm{~cm}$ ) contained only 0.7 percent. Before incubation, $150 \mathrm{ppm}$ of nitrate-nitrogen was added to the samples, which were then either retained as field-moist intact cores, ovendried intact at $212^{\circ} \mathrm{F}\left(100^{\circ} \mathrm{C}\right)$ for 24 hours, or oven-dried at $212^{\circ} \mathrm{F}$ $\left(100^{\circ} \mathrm{C}\right.$ ) for 24 hours, then crushed to less than $1 \mathrm{~mm}$ in diameter. All samples were covered with water to a depth of 1 inch $(2.5 \mathrm{~cm})$ above the soil surface, thereby creating anaerobic conditions favorable for denitrification. The samples were incubated at $64^{\circ}$ to $70^{\circ} \mathrm{F}\left(18^{\circ}\right.$ to $\left.21^{\circ} \mathrm{C}\right)$ for various periods up to 32 days. 


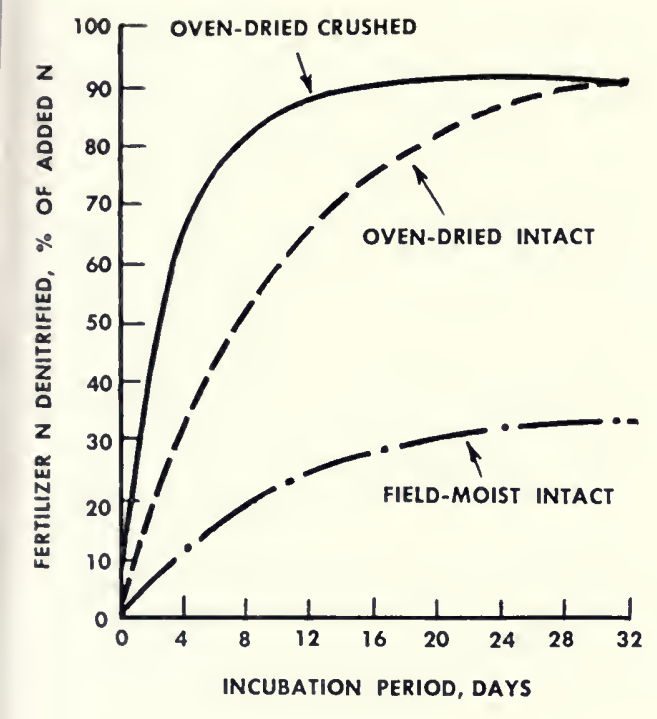

Figure 18. Denitrification as influenced by the physical preparation of soil samples and incubation period. All soil samples were taken from the upper soil horizon and were waterlogged during incubation.

Field-moist intact cores taken from the upper horizon lost about 34 percent of the fertilizer nitrogen through denitrification; oven-dried intact or crushed cores from the upper horizon lost 90 percent (Figure 18). No denitrification occurred in field-moist intact cores from below 12 inches $(30 \mathrm{~cm})$, but those from the lower horizons lost 33 to 66 percent of the fertilizer nitrogen when intact or crushed cores were oven dried. During the 32-day period the maximum daily rate of denitrification in field-moist intact cores taken from the surface was 3.6 percent of the added nitrogen, or about one-third the rate observed in oven-dried intact cores and one-ninth that in oven-dried crushed cores.

The organic matter in soil provides the energy that denitrifying bacteria need to be active. Drying and crushing the samples before incubation apparently increased the available supply of energy, because more nitrogen denitrified from these samples than from the field-moist intact cores. The data indicate that denitrification from field-moist intact cores occurred primarily in samples from the surface horizon, where organic matter is usually more abundant than in deeper horizons. Once nitrogen has leached below the rooting depth of plants, it is preferred that it be denitrified rather than drain from the field into streams or enter underground water supplies. The study indicates that nitrogen leached from the surface horizon of Drummer silty clay is no longer easily denitrified. 
In another experiment denitrification and leaching were studied under field conditions from June 6, 1973, to April 24, 1974 (McKenzie, 1975). On June 6 about 100 pounds of nitrate-nitrogen per acre (112 $\mathrm{kg} / \mathrm{ha}$ ) and chloride were added to field plots, which were then left fallow throughout the study. At the same concentration on a chemically equivalent basis, nitrate and chloride were assumed to leach at the same rate. Because chloride does not denitrify, the difference between the amounts of leached nitrate and chloride represents the amount of nitrate lost by denitrification.

Calculations showed that with Drummer soil more than 50 percent of the fertilizer nitrogen had been lost through denitrification primarily during the first 51 days of the experiment. Denitrification occurred in the upper 14 inches $(35 \mathrm{~cm})$ of soil. Only about 5 percent of the nitrogen had leached deeper than 56 inches $(142 \mathrm{~cm}$ ) between June 6 and November 6. By April 24, however, nearly all of the nitrogen remaining on November 6 had leached below 56 inches. If the land used in this study liad been cropped to corn rather than left fallow, less nitrogen would undoubtedly have been lost because much of it would have been absorbed by the corn. The corn would also have taken up water from the soil, thereby reducing the leaching potential and creating aerobic conditions that inhibit denitrification.

\section{SUMMARY}

Most plants absorb more nitrogen than any other nutrient. Because the amount needed is so large and can easily be lost from many soils, nitrogen is usually the most limiting nutrient for plant growth. Although about 79 percent of the atmosphere is nitrogen, only nitrogen-fixing plants such as legumes with their associated bacteria are able to use this abundant source. The nonleguminous grain crops must receive supplemental nitrogen to produce satisfactory yields. Until the last few decades the supply of available nitrogen in the soil was increased primarily by legumes and manure. These sources should be used when economically feasible, but many important grain-producing areas of the world must now rely on commercial fertilizer nitrogen.

For economic reasons researchers and growers have been interested for many years in improving yields from each unit of nitrogen. Recently, however, the efficient use of nitrogen has become an environmental issue as well, because high nitrate concentrations in water may be harmful to humans, especially infants, and to livestock. If plants absorb more of the added fertilizer nitrogen, then less is likely to leach from fields into drinking water. Improving nitrogen efficiency has also become 
crucial in order to conserve dwindling supplies of natural gas, which is used in large quantities to manufacture nitrogen fertilizers.

In Illinois in 1950 only about 8 percent of the nitrogen removed in harvested grain was supplied by commercial nitrogen fertilizer. Soon after 1950, however, the use of commercial nitrogen began to soar. In 1964 more nitrogen was added for corn than was removed by the grain, a trend that continues to the present. Much of this unabsorbed nitrogen can leach or denitrify.

The relation between crop yield and rate of added nitrogen follows the law of diminishing returns. Results of an eight-year study at Hartsburg indicated that the first 30 -pound-per-acre $(34 \mathrm{~kg} / \mathrm{ha})$ increment of nitrogen increased corn yields 21 bushels per acre (13.2 q/ha), but the increment from 180 to 210 pounds ( 201 to $235 \mathrm{~kg} / \mathrm{ha}$ ) increased the yield only 1 bushel per acre $(0.6 \mathrm{q} / \mathrm{ha})$. Nitrogen recovered in the harvested grain was 56 percent for the first increments but only 3 percent for the latter. Less than 1 pound of the latter increment was harvested; 29 pounds remained in the stover and soil or was lost by leaching and denitrification. Thus the potential for high nitrate levels in drainage water is much greater at high than at low nitrogen rates.

When nitrogen is not taken up by plants the same year it is applied, most of it is unavailable for future crops, according to research findings at Urbana and DeKalb. Although as much as 2,880 pounds per acre $(3,240 \mathrm{~kg} / \mathrm{ha})$ had been applied to the DeKalb plots during an eight-year period, the residual nitrogen was less effective in increasing ninth-year corn yields than 80 pounds ( $90 \mathrm{~kg} / \mathrm{ha}$ ) applied during the ninth year to previously unfertilized plots. Residual nitrogen also produced low yield increases on Urbana plots that had received 320 pounds of nitrogen per acre $(360 \mathrm{~kg} / \mathrm{ha})$ during each of five preceding years. Much of the nitrogen left over after plant uptake undoubtedly leached or denitrified.

Good management practices contribute directly to the efficiency of nitrogen fertilizer. An early corn planting date, for example, and an adequate level of other nutrients enhance nitrogen uptake. Spring rather than fall application is more efficient because nitrogen is apparently lost between fall and spring.

In related research, water from tiles draining growers' fields was analyzed for nitrate during a three-year period. The water from some tiles exceeded the public health standard of $10 \mathrm{mg} / \mathrm{l}$; other tiles were well below this limit. The nitrate-nitrogen concentration averaged for all tiles in the study was $10 \mathrm{mg} / 1$.

Soil samples collected during studies of nitrogen rates indicate that nitrogen movement into the subsoil occurs with high rates of applied 
fertilizer nitrogen. The rates commonly used by growers do not, however, lead to excessively high levels of unused nitrogen.

A corn-soybean rotation effectively cuts down the amount of nitrate leaching into the subsoil because soybeans serve as scavengers for residual nitrogen. Research at Elwood has shown that continuous corn plots contained more nitrate in the spring than did plots planted to soybeans the previous year in a corn-soybean rotation. As a result of this rotation, which is widely used in Illinois, the amount of fertilizer nitrogen applied to rotation fields during two years is only half the amount added to continuous corn fields for the same period.

Nitrogen is far less apt to leach in the ammonium form than in the nitrate form. Chemicals that inhibit the bacterial conversion (nitrification) of ammonium to nitrate have now been made available to help keep nitrogen in its less leachable form. Although nitrification inhibitors unquestionably slow down nitrification, they do not necessarily lead to corn yield increases. A few researchers have reported yield increases, but researchers in Illinois and other states have found that yields are often unaffected by the use of inhibitors.

\section{LITERATURE CITED}

Alexander, M. 1965. Nitrification. Agron. Mono. 10:307-343. Amer. Soc. Agron., Madison, Wisc.

Barber, S. A., and R. A. Olson. 1968. Fertilizer use on corn. Pages 163-188 in L. B. Nelson, M. H. McVickar, R. D. Munson, L. F. Seatz, S. L. Tisdale, and W. C. White, eds., Changing Patterns in Fertilizer Use. Soil Sci. Soc. Amer, Madison, Wisc.

Bauer, F. C., A. L. Lang, C. J. Badger, L. B. Miller, C. H. Farnham, P. E. Johnson, L. F. Marriott, and M. H. Nelson. 1945. Effects of soil treatment on soil productivity - A summary of long-time field experiments. Ill. Agr. Exp. Sta. Bull. 516.

Bauer, F. D., R. S. Smith, and L. H. Smith. 1926. The Illinois soil experiment fields. Ill. Agr. Exp. Sta. Bull. 273.

Bomke, A. A. 1972. Effect of time and rate of nitrogen application to corn on nitrate leaching. Unpublished Ph.D. diss., Univ. of Illinois at Urbana-Champaign.

Boone, L. V., and L. F. Welch. 1972. The more nitrogen in corn, the less in our water supply. Ill. Res. 14(4):5-6.

Boswell, F. C. 1977. Seasonal anhydrous ammonia comparison for corn with and without a nitrification inhibitor. Agron. J. 69:103-106.

Broadbent, F. E., and F. Clark. 1965. Denitrification. Agron. Mono. 10:344-359. Amer. Soc. Agron., Madison, Wisc.

Deeb, B. S., and K. W. Sloan. 1975. Nitrates, nitrites, and health. Ill. Agr. Exp. Sta. Bull. 750.

Dibb, D. W., and L. F. Welch. 1976. Corn growth as affected by ammonia vs. nitrate absorbed from soil. Agron. J. 68:89-94. 
Dickey, E. C., and W. D. Lembke. 1978. Wells and ponds: Water supply and quality. Ill. Agr. Exp. Sta. Bull. 758.

Gentzsch, E. P., E. C. A. Runge, and T. R. Peck. 1974. Nitrate occurrence in some soils with and without natric horizons. J. Environ. Qual. $3: 89-94$.

Goring, C. A. I. 1962. Control of nitrification by 2-chloro-6-(trichloromethyl) pyridinc. Soil Sci. $93: 211-218$.

Huber, D. M., H. L. Warren, D. W. Nelson, and C. V. Tsai. 1977. Nitrification inhibitors - New tools for food production. BioScience $27: 523-529$.

Hughes, T. D., and L. F. Welch. 1970. 2-chloro-6-(trichloromethyl) pyridine as a nitrification inhibitor for anhydrous ammonia applied in different season. Agron. J. $62: 821-824$.

Johnson, J. W., L. F. Welch, and L. T. Kurtz. 1975. Environmental implications of $\mathrm{N}$ fixations by soybeans. J. Environ. Qual. 4:303-306.

Kapusta, G., and E. C. Varsa. 1972. Nitrification inhibitors - Do they work? Down to Earth 28(1):21-23.

Kurtz, L. T. 1970. The fate of applied nutrients in soils. J. Agr. Food Chem. $18: 773-780$.

Mays, D. A. 1974. Forage Fertilization. Amer. Soc. Agron., Crop Sci. Soc. Amer., and Soil Sci. Soc. Amer. 621p. Madison, Wisc.

McKenzie, E., Jr. 1975. Loss of ${ }^{15} \mathrm{~N}$-labeled fertilizer nitrogen from some Illinois soil profiles by denitrification and/or leaching. Unpublished Ph.D. diss., Univ. of Illinois at Urbana-Champaign.

McKenzie, E., Jr., and L. T. Kurtz. 1976. Effect of pretreatment on loss of nitrogen-15-labelled fertilizer nitrogen from waterlogged soil during incubation. Soil Sci. Soc. Amer. J. $40: 534-536$.

McKibben, G. E. 1975. Update 75. A research report of the Dixon Springs Agricultural Center. Ill. Agr. Exp. Sta. DSAC-3.

Miller, L. B., and A. L. Lang. 1961. Nitrogen for corn - Summary of results, Illinois experiment fields, 1943-1960. 11l. Agr. Exp. Sta., Dept. Agron. AG-1777.

Mulvaney, D. L., R. R. Bell, D. E. Harslibarger, and L. V. Boone. 1976. Report of research results - Northern Illinois and northeastern Illinois agronomy research centers and Dixon agronomy research field. Ill. Agr. Exp. Sta., Dept. Agron. AG-2012.

Owens, L. D. 1960. Nitrogen movement and transformation in soils as evaluated by a lysimeter study utilizing isotopic nitrogen. Soil Sci. Soc. Amer. Proc. 24 :372376.

Prasad, R., G. B. Rajale, and B. A. Lakhdive. 1971. Nitrification retarders and slow-release nitrogen fertilizers. Adv. Agron. 23 :337-383.

Sabey, B. R. 1968. The influence of nitrification suppressants on the rate of ammonium oxidation in midwestern USA field soils. Soil Sci. Soc. Amer. Proc. $32: 675-679$.

Stevenson, F. J. 1965. Origin and distribution of nitrogen in soil. In W. V. Bartholonew and F. E. Clark, eds., Soil Nitrogen. Agronomy 10:1-42. Amer. Soc. Agron., Madison, Wisc.

Swanson, E. R., C. R. Taylor, and P. J. van Blockland. 1978. Economic effects of nitrogen fertilizer controls. Ill. Agr. Exp. Sta. Bull. 757.

Swanson, E. R., C. R. Taylor, and L. F. Welch. 1973. Economically optimal levels of nitrogen fertilizer for corn: An analysis based on experimental data, 19661971. Ill. Agr. Econ. 13(2) :16-25. 
Swezey, A. W., and G. O. Turner. 1962. Crop experiments on the effect of 2chloro-6-(trichloromethyl) pyridine for the control of nitrification of ammonium and urea fertilizers. Agron. J. 54:532-535.

Tisdale, S. L., and W. L. Nelson. 1975. Soil Fertility and Fertilizers. 3rd Ed. 492p. Macmillan Publishing Co.: New York.

Touchton, J. T., R. G. Hoeft, and L. F. Welch. 1978a. Effect of nitrapyrin on nitrification of fall- and spring-applied anhydrous ammonia. Agron. J. 70: 805-810.

- 1978b. Effect of nitrapyrin on nitrification of urea, nutrient uptake by corn, and corn yield. Agron. J. (In Press)

- 1978c. Nitrogen uptake and corn yield as affected by applications of nitrapyrin with anhydrous ammonia. Agron. J. (In Press)

Walsh, L. M. 1977. Should you be using nitrapyrin? Crops and Soils 30(1):8-10.

Walton, W. C. 1965. Ground-water recharge and runoff in Illinois. Illinois State Water Survey, Urbana, Report of Investigation 48.

Warren, H. L., D. M. Huber, D. W. Nelson, and O. W. Mann. 1975. Stalk rot incidence and yield of corn as affected by inhibiting nitrification of fall-applied ammonium. Agron. J. 67 :655-660.

Welch, L. F. 1972. More nutrients are added to soil than are hauled away in crops. Ill. Res. 14(1):3-4.

- 1977. Foliar fertilization. Illinois Fertilizer Conf. Proc. Pp. 3-8.

Welch, L. F., L. V. Boone, C. G. Chambliss, A. T. Christiansen, D. L. Mulvaney, M. G. Oldham, and J. W. Pendleton. 1973. Soybean yields with direct and residual nitrogen fertilization. Agron. J. 65 : 547-550.

Welch L. F., P. E. Johnson, J. W. Pendleton, and L. B. Miller. 1966. Efficiency of fall- versus spring-applied nitrogen for winter wheat. Agron. J. 58:271-274.

Welch, L. F., D. L. Mulvaney, M. G. Oldham, L. V. Boone, and J. W. Pendleton. 1971. Corn yields with fall, spring, and sidedress nitrogen. Agron. J. 63:119-123.

Westerman, R L., and L. T. Kurtz. 1972. Residual effects of ${ }^{15} \mathrm{~N}$-labeled fertilizers in a field study. Soil Sci. Soc. Amer. Proc. 36:91-94. 



\section{METRIC CONVERSION CHART}

Both English and metric units are used throughout this bulletin. Conversions for some measurements commonly used in the report are given below. For simplicity, many metric equivalents in the text, tables, and figures have been rounded.

\section{English \\ Metric}

1 inch, in........... 2.54 centimeters, $\mathrm{cm}$

I acre, A............ 0.40 hectare, ha

I pound, lb........... 0.45 kilogram, kg

I short ton............. 0.91 metric ton

1 pound per acre, $\mathrm{lb} / \mathrm{A} \ldots \ldots .1 .12$ kilograms per hectare, $\mathrm{kg} / \mathrm{ha}$

1 bushel per acre, bu/A:

Corn $(56 \mathrm{lb}) \ldots \ldots \ldots \ldots .0 .63$ quintal $^{*}$ per hectare, $\mathrm{q} / \mathrm{ha}$

Soybeans $(60 \mathrm{lb}) \ldots \ldots \ldots . .60 .67$ quintal per hectare

Wheat $(60 \mathrm{lb}) \ldots \ldots \ldots .0 .67$ quintal per hectare

* 1 quintal $=100$ kilograms. 





UNIVERSITY OF ILLINOIS-URBANA

0.630.71L68

BULLETIN. URBANA

COOP

751.765 1975-81

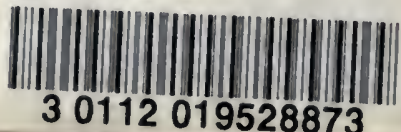

